\title{
norden
}

\section{Nordiske velfærdsalliancer}

Erfaringer fra samarbejde om holdbar nordisk velfærd
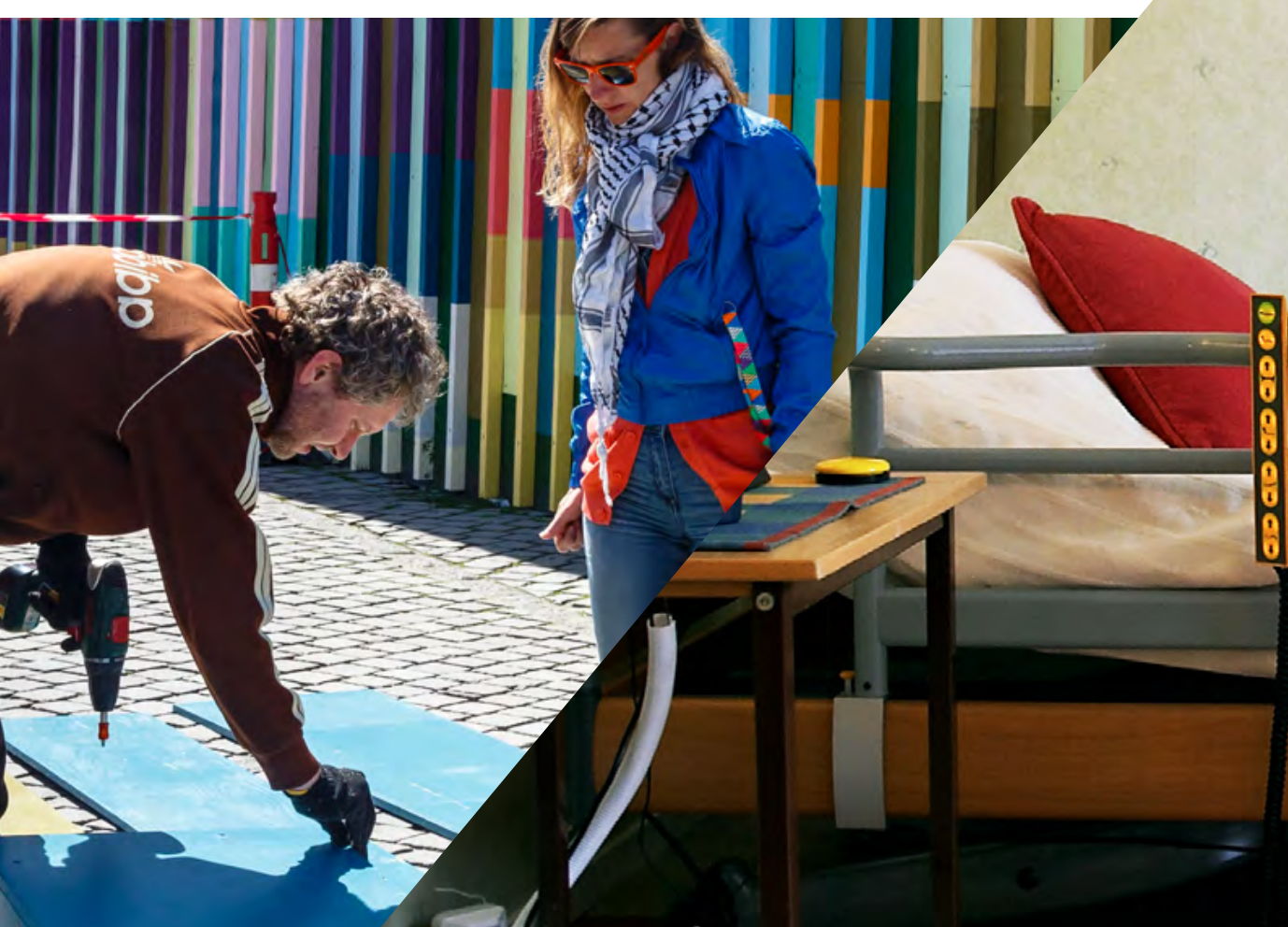


\section{Nordiske Velfærdsalliancer}

Erfaringer fra samarbejde om holdbar

nordisk velfærd

Mandag Morgen

ISBN 978-92-893-4457-9 (PRINT)

ISBN 978-92-893-4458-6 (PDF)

http://dx.doi.org/10.6027/ANP2016-704

ANP 2016:704

(C) Nordisk Ministerråd 2016

Layout: Gitte Wejnold

Omslagsfoto: Norden.org

Foto: Norden.org, SignElements.com

Skrift: Meta LF

Printed in Denmark

www.norden.org/publications

\section{Det nordiske samarbejde}

Det nordiske samarbejde er en af verdens mest omfattende regionale samarbejdsformer. Samarbejdet omfatter Danmark, Finland, Island, Norge og Sverige samt Færøerne, Grønland og Åland.

Det nordiske samarbejde er både politisk, økonomisk og kulturelt forankret, og er en vigtig medspiller i det europæiske og internationale samarbejde. Det nordiske fællesskab arbejder for et stærkt Norden i et stærkt Europa.

Det nordiske samarbejde ønsker at styrke nordiske og regionale interesser og værdier i en global omverden. Fælles værdier landene imellem er med til at styrke Nordens position som en af verdens mest innovative og konkurrencedygtige regioner.

\section{Nordisk Ministerråd}

Ved Stranden 18

1061 København K

Telefon (+45) 33960200

www.norden.org 


\section{Nordiske velfærdsalliancer}

Erfaringer fra samarbejde om holdbar nordisk velfærd 


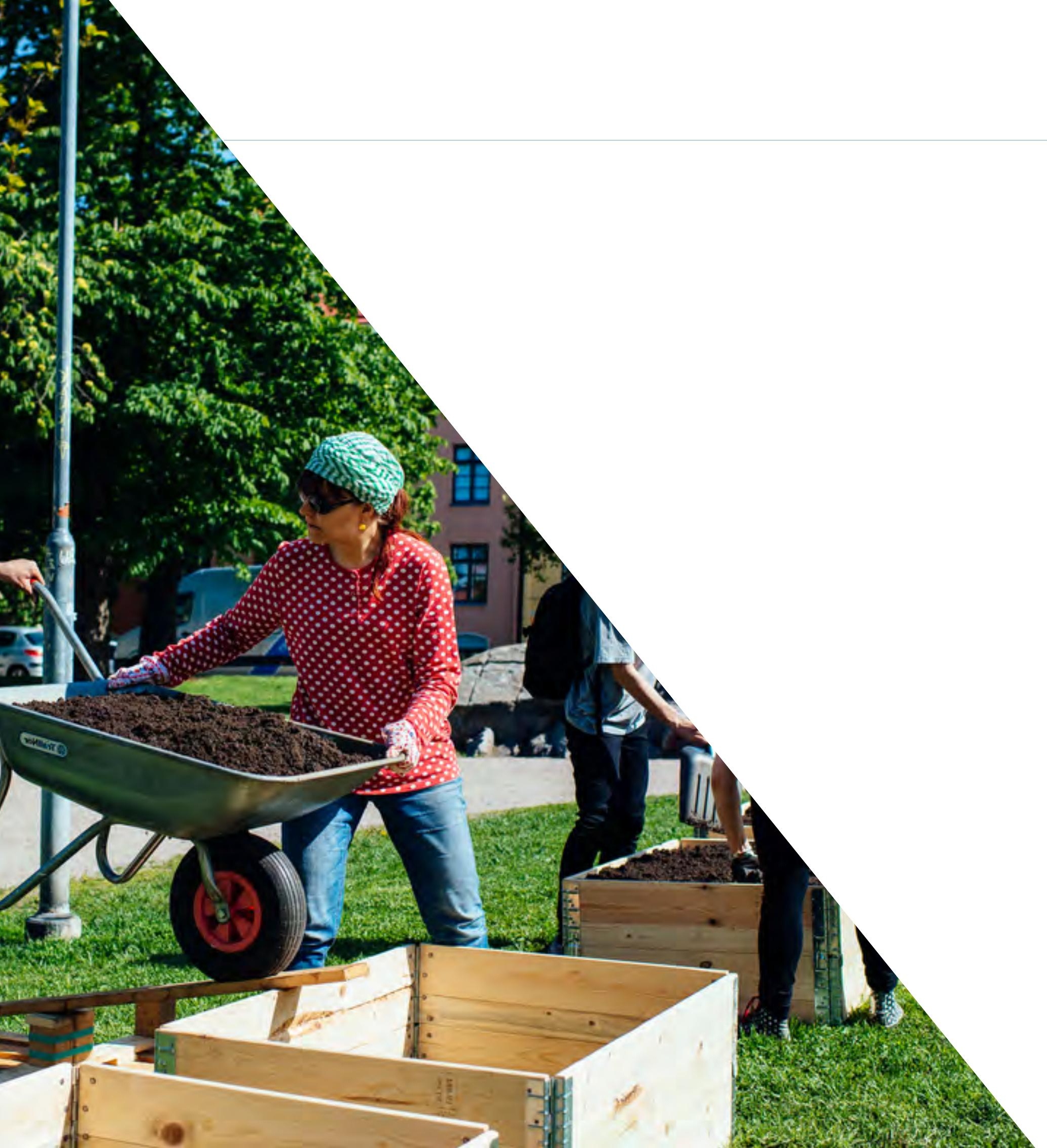




\section{Indhold}

\section{Forord}

Sammen om velferd 6

Om “Holdbar Nordisk Velfærd” 9

$\begin{array}{ll}\text { Læsevejledning } & 6\end{array}$

Afsæt

Velfærd i verdensklasse ... også i fremtiden?

Artikel

Læger bryder grænser

Artikel

Teknologi styrker fremtidens pleje

Artikel

Fælles fodslag sikrer flere faglærte

Ekspertinterview

Innovation på nordisk

Artikel

Flydende data skaber bedre viden

Efterskrift

Arbejdet fortsætter

Vejen videre - et nyt program

60

Projektgalleri

Dem har vi talt med 


\section{Sammen om velferd}

I de nordiske landene opplever vi en stigende anerkjennelse for vår evne til å kombinere økonomisk vekst med velferd i en særlig "nordisk modell". Stadig flere ser til vår måte å innrette samfunnet på - og det er vi stolte av.

Men selv en sterk modell må utvikles og tilpasses for ikke å gå i stå, og finanskrise, global konkurranse, digitalisering og den demografiske utviklingen minner oss om at vi ikke kan ta velferden vår for gitt.

I stedet for å la utfordringer som dette tære på den nordiske modellen, bør vi bruke de utfordringene vi står overfor som anledninger til å ruste den, og til å gjøre velferdssamfunnet vårt i stand til å møte fremtidens globale utfordringer.

Med dette som utgangspunkt satte Nordisk ministerråd i 2013 i gang programmet "Holdbar nordisk velferd". Sammen har vi i løpet av de siste tre årene utviklet ny viten, bragt nye innovative løsninger på banen og gitt inspirasjon til hvordan vi fornyer og forbedrer velferden for Nordens 26 millioner innbyggere.

Vi har lært mye. Nå ser vi hvordan yrkesutdannelsene kan minske arbeidsløsheten blant ungdom, hvordan velferdsteknologi kan sikre helse- og omsorgssektorene for fremtiden, hvordan vi kan opprettholde medisinsk behandling $i$ verdensklasse - også på høyspesialiserte områder - og hvordan fellesnordisk adgang til informasjon kan gi nødvendig viten for å komme stigende ulikhet til livs.

I tillegg har vi lært noe om det nordiske samarbeidet. Dette er viktig viten når vi skal ruste vår nordiske modell for fremtiden.

Vi har lært at vi noen ganger skal bli bedre på å hente løsninger fra et annet nordisk land fremfor selv å starte forfra, at vi noen ganger skal etablere desiderte nordiske enheter - som for eksempel spesialutdan- nede nordiske legeteams. Andre ganger behøver vi ikke gjøre det samme i Norge som vi gjør i Island eller Finland, men likevel ser vi nytten av å snakke mer sammen. Ofte inspirerer kolleger som gjør tingene på en annen måte til refleksjon over hvordan man selv kan gjøre dem bedre.

Det å arbeide sammen tar tid. Men felles for prosjektene $i$ "Holdbar nordisk velferd" er at de viser hvordan samarbeid også gir markant bedre løsninger på felles utfordringer. Tilliten mellom mennesker og mellom organisasjoner er avgjørende for det gode samarbeidet - og den tilliten til hverandre, den har vi heldigvis i Norden.

Derfor styrker "Holdbar nordisk velferd" også min tro på at vi i Norden kan finne en felles drivkraft som kan hjelpe oss med å sikre den nordiske velferden for fremtiden.

Det kommende finske formannskapet fra 2016 er blant dem som tar 
det fortsatte arbeidet for en holdbar nordisk velferd på alvor, når de følger opp på sentrale aspekter fra programmet $i$ deres treårige prioriteringsprosjekt om et innovativt og åpent Norden med mennesker som trives og har like muligheter til velferd, utdanning, kultur og arbeid.

Og jeg håper at resultater og erfaringer fra de siste tre årene kan inspirere andre til å skape enda flere fellesnordiske prosjekter på velferdsområdet.

God leselyst.

Dagfinn Høybråten Gereralsekretær, Nordisk Ministerråd 


\section{Om "Holdbar Nordisk Velfærd"}

Fælles løsninger, der skaber bedre velfærd for borgere i hele Norden, og et bedre videngrundlag at træffe velfærdspolitiske beslutninger om sundhed, uddannelse og arbejdsmarked ud fra. Det er formålet med "Holdbar Nordisk Velfærd" og afspejler de nordiske statsministres ønske om at styrke nordisk samarbejde om velfærdsløsninger fra 2012.

Det ønske er bredt forankret på tværs af sektorområder, og både Ministerrådet for uddannelse og forskning og Ministerrådet for social- og sundhedspolitik er ansvarlige for initiativet, der fokuserer på samarbejde inden for tre områder:

Forskning for velfærd, som handler om at skabe ny viden, der kan bidrage til velfærd for alle.

Uddannelse og arbejde til velfærd, som fokuserer på at styrke uddannelser og arbejdsmarkeder i Norden.

Infrastruktur for velfærd, som koncentrerer sig om at udvikle og kvalitetssikre de nordiske sundhedsvæsener.

"Holdbar Nordisk Velfærd" finansierer 17 samarbejdsprojekter med i alt 73.210.614 mio. DKK i perioden 2013-2015. Du kan danne dig et overblik over projekterne i galleriet på side 62 og læse mere om programmet på www.norden.org/vaelfaerd

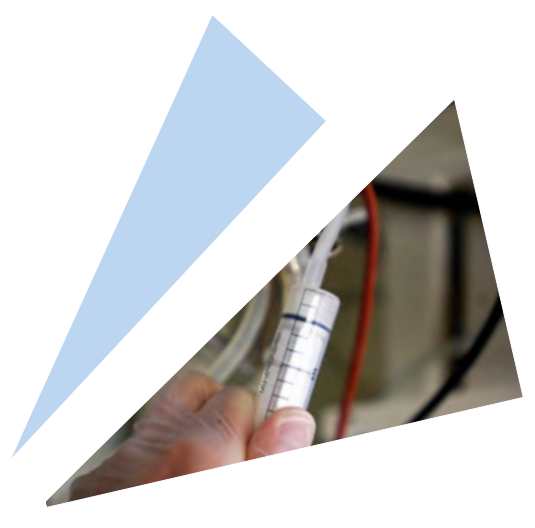




\section{Læsevejledning}

Den publikation, du sidder med $\mathrm{i}$ hånden, er en fortælling om nordisk samarbejde. Under overskriften "Holdbar Nordisk Velfærd" har gode kræfter fra alle nordiske lande de seneste tre år arbejdet sammen om at finde nye veje til bedre velfærd.

\section{7 forskellige projekter med fokus} på sundhed, uddannelse og arbejdsmarked udgør kernen i samarbejdet. Det er erfaringer og resultater fra de projekter, som er udgangspunktet for fortællingen her. Tilsammen og hver for sig fortæller projekterne noget om, hvordan det giver mening at samarbejde på tværs af Norden. Og hvad samarbejdet kræver.

Du kan danne dig et overblik over projekterne i "Holdbar Nordisk Velfærd” på side 62 .

\section{Det kan du læse om}

I publikationen kan du blive klogere på, hvorfor det giver mening at samarbejde om velfærden i Norden, hvordan samarbejdet ser ud i praksis, og hvordan vi bliver endnu bedre til at samarbejde i fremtiden.

Vi starter på side 12 med at dykke ned i udgangspunktet for samarbejdet - den nordiske model. Du kan også læse om nogle af de fælles udfordringer, som kalder på mere samarbejde på tværs af grænserne.

Herefter finder du fire eksempler på, hvordan det nordiske samarbejde om velfærd kan se ud i praksis:

- I artiklen “Læger bryder grænser” kan du blive klogere på, hvordan nye nordiske samarbejder inden for højt specialiserede behandlinger baner vejen for viden, uddannelse og faglige miljøer i verdensklasse på de nordiske hospitaler.

- I artiklen "Teknologi styrker fremtidens pleje” kan du læse om, hvordan et nordisk netværk af frontløberkommuner arbejder sammen om at udvikle en fælles model for arbejdet med velfærdsteknologi - til gavn for både ældre og velfærdsprofessionelle i hele Norden.

- I artiklen "Fælles fodslag sikrer flere faglærte" kan du blive klogere på, hvordan et nordisk netværk med både lokale og nationale aktører bringer forskellighederne i spil for at få idéer til, hvordan de kan løfte erhvervsuddannelser i Norden og give flere unge fodfæste på arbejdsmarkedet.

- I artiklen "Flydende data skaber bedre viden" kan du læse om, hvordan et nyt nordisk samarbejde arbejder på at nedbryde barriererne for datadeling på tværs af de nordiske lande for at hjælpe forskere på vej mod ny viden. Viden som på sigt kan komme alle de nordiske velfærdssamfund til gavn. 
Hver for sig illustrerer eksemplerne nogle af de gevinster, vi kan høste ved at samarbejde, og hvad vi skal huske undervejs, hvis samarbejdet skal lykkes. Og så er de stærke billeder på, at det nordiske samarbejde om velfærd kan tage mange forskellige former. Nogle gange handler det om at tale sammen og bruge vores forskelligheder til at blive klogere på os selv og hinanden. Andre gange handler det om at finde fælles fodslag og udvikle fælles løsninger.

Undervejs i fortællingen gør vi holdt og tager temperaturen på den nordiske innovationskraft. Læs eksperternes indspark på side 46 .

Fortællingen slutter på side 58 med projektdeltagernes bud på en tjekliste til det gode samarbejde. Her kan du også læse mere om, hvordan arbejdet med at udvikle holdbar velfærd fortsætter under det finske formandskab i Nordisk Ministerråd i 2016. 


\section{Velfærd i verdensklasse}

De nordiske lande har noget til fælles, som er helt unikt. Gennem årtier har Norden vist sig i stand til at forene økonomisk vækst, velfærd og social lighed - en evne, som har gjort den særlige "nordiske model" til et forbillede i international sammenhæng. Men også de nordiske lande blev ramt hårdt af finanskrisen og mindet om, at den nordiske model ikke kan tages for givet. Her på siderne kan du læse om, hvad der kendetegner den nordiske model, og nogle af de største udfordringer, den står over for.

\section{Lighed og velstand \\ - en nordisk disciplin}

Høj levestandard, lighed i indkomst og lav fattigdom er kendetegnende for alle de nordiske lande. De tre kendetegn er resultatet af en nordisk model båret af universelle, skattefinansierede velfærdsydelser, store investeringer i uddannelse, børnepasning mv. og et arbejdsmarked, som forener social sikkerhed og fleksibilitet. De nordiske lande ligger helt i top internationalt, når det handler om kombinationen af velstand og lighed. Se figur 1 og 2.

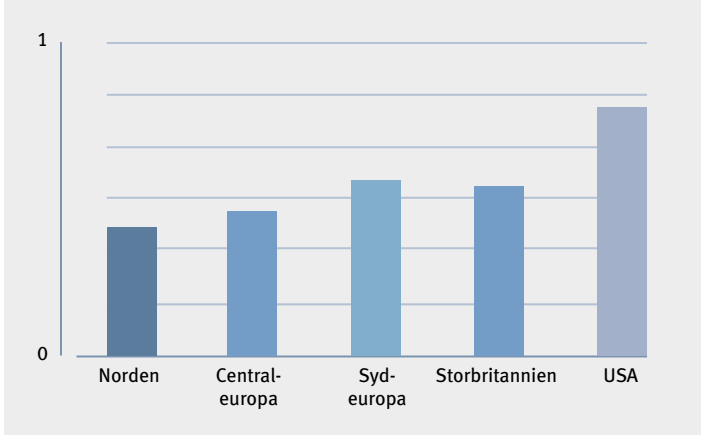

Figur 1

\section{De nordiske lande er lige.}

Forklaring: Til at måle indkomstuligheden bruger man den såkaldte Ginikoefficient. Det er et indeks mellem 0 og 1 , hvor 0 svarer til, at alle personer har samme indkomstniveau, mens 1 svarer til, at hele indkomsten er samlet hos én person. Jo mere lige fordelingen af indkomst er, jo lavere vil Ginikoefficienten være.

Norden dækker Danmark, Finland, Island, Norge og Sverige. Centraleuropa dækker Østrig, Belgien, Frankrig, Tyskland og Holland og Sydeuropa refererer til Grækenland, Italien, Portugal og Spanien. Kilde: Eurostat $i$ The Nordic model - challenged but capable of reform, Nordisk Ministerråd, 2014

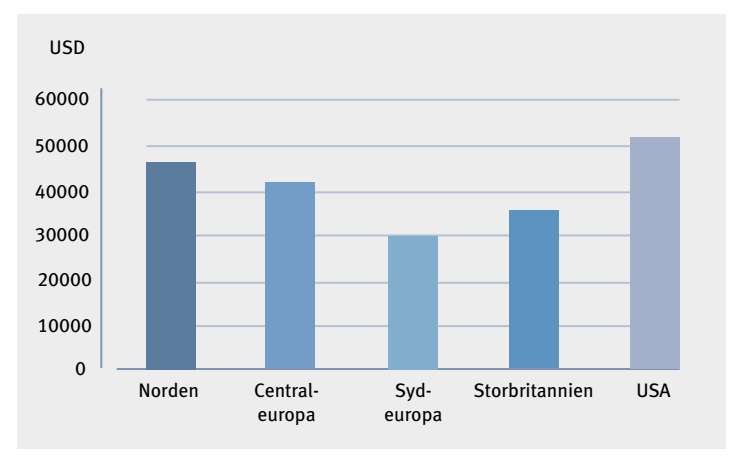

Figur 2

De nordiske lande er rige.

Forklaring: Gennemsnitlig BNP per indbygger i USD. Norden dækker Danmark, Finland, Island, Norge og Sverige. Centraleuropa dækker $\emptyset$ strig, Belgien, Frankrig, Tyskland og Holland og Sydeuropa refererer til Grækenland, Italien, Portugal og Spanien.

Kilde: OECD $i$ The Nordic Model - challenged but capable of reform, Nordisk Ministerråd, 2014. 


\section{Velfærd, der virker}

Staten er ikke populær i de nordiske lande, fordi den er stor, men fordi den virker. Nogenlunde sådan skrev det internationale tidsskrift The Economist, da det i 2013 udnævnte den nordiske model til at være "the next supermodel", som andre lande verden over bør tage ved lære af. Og der er noget om snakken. De fleste målinger viser, at de nordiske lande har en offentlig sektor, der ikke kun hører til blandt de største i verden, men også blandt de meste effektive. Se figur 3.

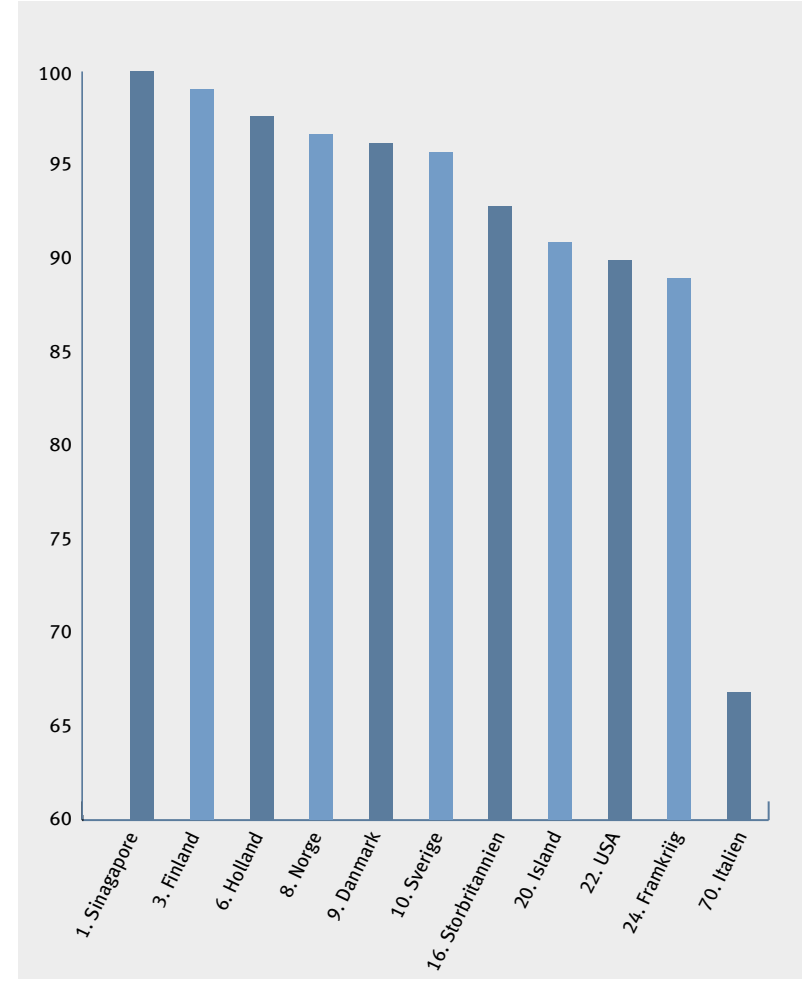

Figur 3

Alle de nordiske lande ligger $i$ top $i$ internationale sammenligninger af offentlige sektorers effektivitet.

Forklaring: Tallene bygger på en lang række survey-undersøgelser af både virksomheders, borgeres og eksperters syn på den offentlige sektors kvalitet. Mest effektiv $=$ indeks 100 .

Kilde: Government Effectiveness, Worldwide Governance Indicators, 2015, World Bank.

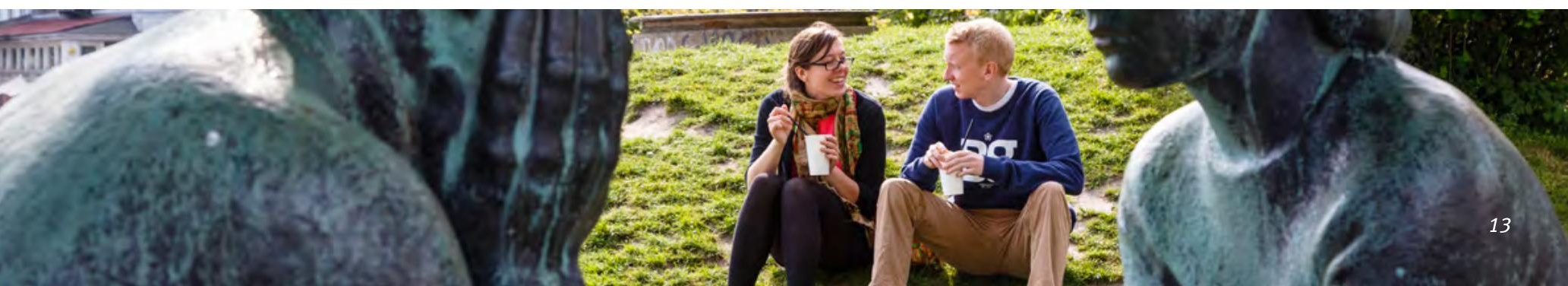




\section{... også i fremtiden?}

En række udfordringer kalder på, at vi nøje overvejer, hvordan vi udvikler den nordiske model, så de nordiske samfund også i fremtiden kan sikre velfærd i verdensklasse. Her får du et indblik i tre af de udfordringer, som i særlig grad - kalder på nytænkning.

\section{Flere ældre, færre hænder}

I løbet af de næste 40 år vil antallet af ældre over 65 år stige støt og komme til at udgøre en stadig større andel af befolkningen i de nordiske lande. Grafen viser andelen af ældre over 65 år set i forhold til den del af befolkningen, som er i den arbejdsdygtige alder. Se figur 5 .

\section{Norden i den globale konkurrence}

Globaliseringen betyder, at både mennesker og virksomheder flytter over landegrænser. Mange nordiske firmaer har allerede i dag store dele af deres ansatte placeret uden for Norden, og konkurrencen for at tiltrække og fastholde virksomheder og kvalificeret arbejdskraft er blevet hårdere. Selvom de nordiske lande har investeret stort i den digitale ud- vikling og skabt nye jobs og nye muligheder i den globale konkurrence, kan udviklingen vende hurtigt. Det er finske Nokia et eksempel på. Frem til 2010 sad firmaet på det globale marked for mobiltelefoner. Så introducerede Apple touchscreen-teknologien og iOS-styresystemet, og på kort tid faldt Nokia fra tinden. Indtil 2011 var Nokia således stadig verdens største producent af smartphones, men de er i dag langt bagefter både Apple og Samsung samt nyere spillere på markedet som fx kinesiske Huawei. Se figur 6.

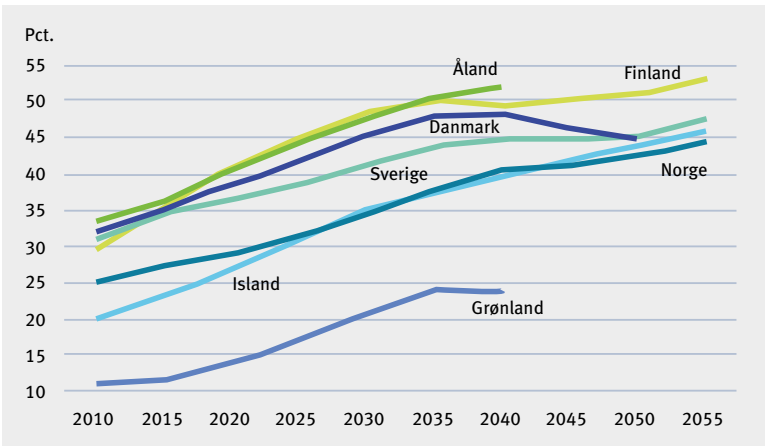

Figur 5

Alle de nordiske lande oplever en demografisk udvikling, som betyder flere ældre og færre hænder i fremtiden.

Forklaring: Den demografiske forsørgerbrøk i de nordiske lande, i procent. Procenttallet udgøres af aldersgruppen 65+ delt med aldersgruppen 20-64 år og ganget med 100.

Kilde: Nordisk statistisk årsbok 2014.

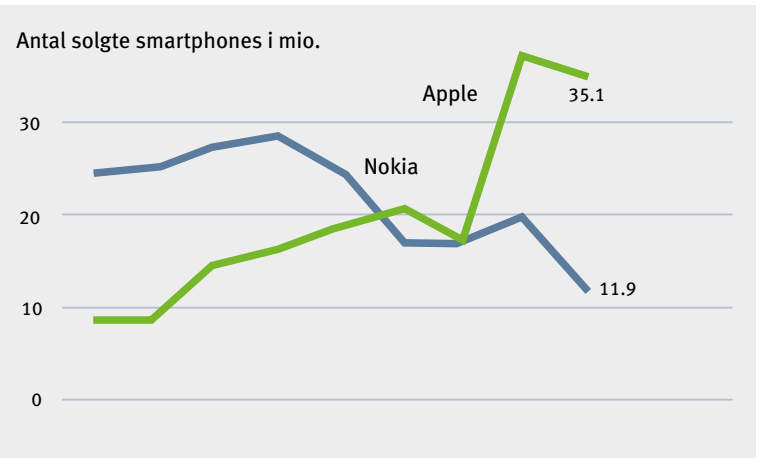

Figur 6

Nokias fald fra tinden. På bare to år tabte den finske elektronikgigant væsentlige markedsandele til konkurrenten Apple.

Forklaring: Figuren viser antallet af solgte mobiltelefoner i millioner fra 1. kvartal 2010 til 1. kvartal 2012.

Kilde: Statista. 


\section{Flere uden for arbejdsmarkedet}

Den teknologiske udvikling betyder, at vi skal indstille os på, at en stor andel af de jobs, vi kender i dag, vil forsvinde i løbet af de næste 10-20 år. Ifølge økonomer kan det føre til en ny type polarisering af det nordiske arbejdsmarked og skabe en større ulighed i befolkningen. De dårligst uddannede vil blive ramt hårdest, hvilket understreger behovet for også i fremtiden at investere i uddannelse og efteruddannelse, som sikrer, at de nordiske befolkninger har kompetencerne til at begå sig på et arbejdsmarked i hastig forandring. Se figur 7 .

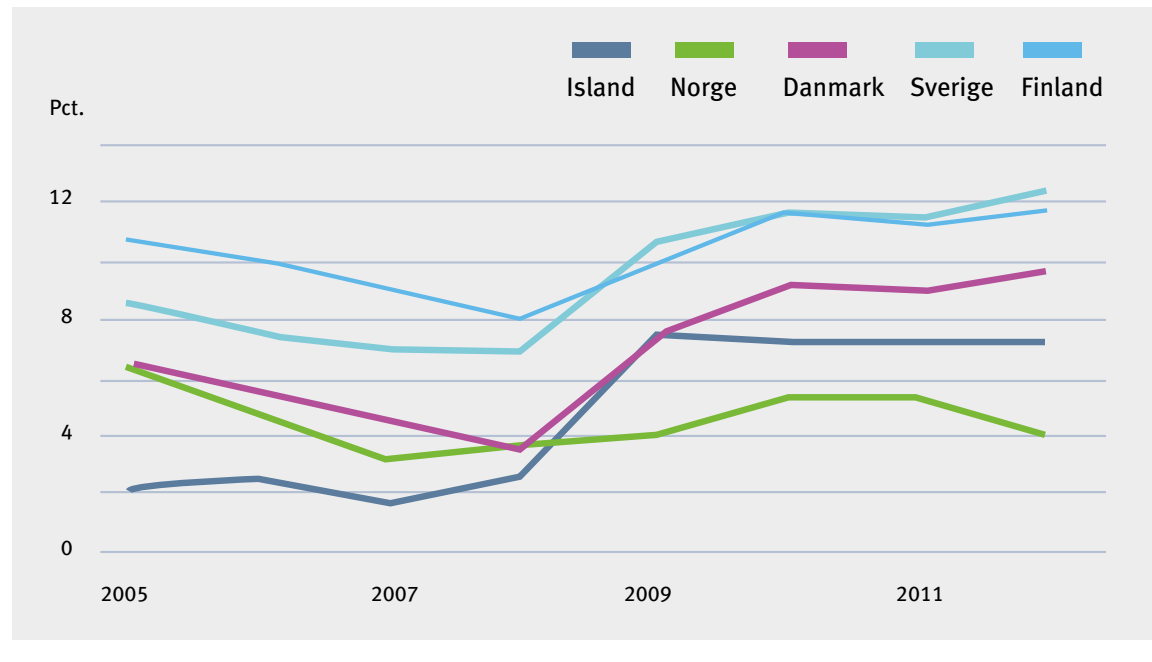

Figur 7

Med undtagelse af Norge er arbejdsløsheden blandt ufaglærte støt stigende $i$ alle de nordiske lande. Forklaring: Arbejdsløshed blandt ufaglærte arbejdere i procent af den samlede ufaglærte arbejdskraft. Kilde: Eurostat $i$ The Nordic Model challenged but capable of reform, Nordisk Ministerråd, 2014.

Boks 1

\section{Vil du vide mere om den nordiske model?}

I rapporten The Nordic model - challenged but capable of reform kan du læse mere om, hvordan den nordiske model egentlig klarer sig - ikke mindst i lyset af finanskrisen. Bag rapporten står en række fremtrædende økonomer fra hele Norden. Rapporten er en del af "Holdbar Nordisk Velfærd".

Se mere i projektgalleriet på side 62.

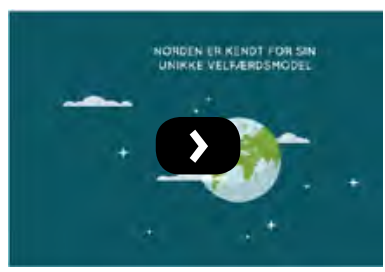

Video:Bliv klogere på den nordiske model 


\title{
Samarbejde $=$ samtale
}

\author{
Hvorfor et program om nye velfærdsløsninger i Norden? Anders Geertsen, \\ afdelingschef i Kundskab og Velfærd, Nordisk Ministerråd, reflekterer over tre \\ års erfaringer med samarbejdet om velfærd og sætter ord på gevinsterne.
}

\section{Hvorfor skal vi have et nordisk samarbejde om velfærd?}

De nordiske lande har altid haft et stærkt fundament for at samarbejde. Sat på spidsen har vi jo trods alt været ét land i 800 af de seneste 1.000 år, og mange af de udfordringer, som vi deler på tværs af de nordiske grænser, kan vi løse bedre, hvis vi samarbejder. Tag globaliseringen som eksempel. De nordiske lande hver for sig er nærmest miniputstater i såvel europæisk som i verdenssammenhæng. Det betyder, at vi på mange måder har færre muskler end de store lande, og at vi i nogle tilfælde er nødt til at slå os sammen for fortsat at bevare den nordiske førerposition, eksempelvis inden for sundhed.

\section{Hvad vil det sige at samarbejde?}

I min optik starter al samarbejde i virkeligheden med samtalen. Derfor vil jeg også hellere tale om nordiske samtaler mellem fem lande end om samarbejdsprojekter, fordi samtalen altid er første skridt, hvis vi skal lære af hinanden.

Fælles udfordringer kalder ikke nødvendigvis på ens løsninger, men de kalder på en dialog, hvor vi kan blive klogere på os selv og hinanden. Og dialog er vi rigtig gode til i Norden, fordi vi har stor tillid til hinanden landene imellem. Det skaber fundamentet for at erfaringsudveksle. Samtalen har en værdi i sig selv, fordi den skaber netværk
- og måske, men ikke altid, munder samtalen ud i konkrete aftaler eller skaber nye initiativer.

\section{Hvor langt er vi kommet i løbet af de sidste tre år?}

På tre år har vi selvfølgelig heller ikke fundet én forkromet universalløsning på de udfordringer, som de nordiske velfærdssamfund står over for. Når vi taler om udfordringer som globalisering, demografiske forandringer eller stigende ulighed på arbejdsmarkedet, skal der mange forskellige Øøsninger til. Det, vi til gengæld er lykkedes med, er dels at sætte noget af det, vi hver især kæmper med, på en fælles dagsorden, dels at dele de idéer og løsninger, vi hver især arbejder med. De ahaoplevelser, nye idéer og inspiration, vi opnår sammen, er vigtige brikker i forhold til at håndtere de overordnede udfordringer.

\section{Hvor skal samarbejdet om velfærdsløsninger bevæge sig hen nu?}

Hvert enkelt af de 17 projekter i programmet "Holdbar Nordisk Velfærd" har startet en samtale, som det er afgørende, at vi fortsætter. Vi skal blive ved med at udfordre vores nordiske selvforståelse af, at vi er de bedste i verden. Vi skal bruge hinanden og samtalen til at booste vores evne til at tænke nyt, så vi hele tiden spørger os selv: "Hvordan kan vi gøre tingene anderledes og bedre? Og hvad er det, vi skal gøre anderledes i morgen og om 10 år?” 


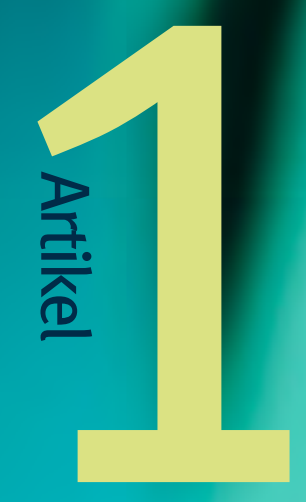

Læger

bryder

grænser 


\section{6 patienter. Så mange} svenskere opererer lægerne på S:t Eriks Ögonsjukhus i Sverige hvert år for retinoblastom, som er en sjælden, medfødt kræftsygdom i øjet. I Danmark er tallet 5 og i Norge 4. Behandlingen af retinoblastom er ét eksempel på en af mange såkaldt højt specialiserede behandlinger, hvor det giver særligt god mening at samarbejde på tværs af Norden. De nordiske sygehuse møder nemlig kun et fåtal af patienter med retinoblastom hvert år, og det $g ø r$ det svært for læger, som gerne vil specialisere sig i behandlingen.

"Det er ikke altid, at vores sundhedspersonale bliver dygtigst, hvis vi kun har et nationalt perspektiv. Det gælder særligt for højt specialiseret behandling, hvor samarbejdet på tværs af grænser helt lavpraktisk $\emptyset$ ger antallet af patienter. Det betyder, at lægerne i de faglige miljøer kan opbygge den nødvendige erfaring, og at vi får uddannelser, som er opdaterede på den nyeste viden og forskning," fortæller Hans Petter Aarseth, som er projektdirektør i Helsedirektoratet i Oslo.

De sidste tre år har han stået i spidsen for et projekt, der har undersøgt mulighederne for flere nordiske samarbejder om højt specialiseret behandling. Læs mere om de konkrete initiativer, som er etableret under projektet $i$ boks 2 .
Samarbejdet er afgørende, fordi vi ikke må gå på kompromis med kvaliteten af behandlingen, bare fordi vi er små lande, understreger Hans Petter Aarseth.

"Et sundhedsvæsen i verdensklasse udgør en grundpille i hvert af de nordiske velfærdssamfund, og det nordiske perspektiv er i hvert fald ét svar på nogle af de begrænsninger, som de enkelte landes størrelser giver os i den forbindelse. Gevinsten $i$ at samarbejde på tværs af Norden ligger ligefor: Vi får dygtigere læger og i sidste ende større kvalitet $i$ behandlingen af borgerne," fortæller Hans Petter Aarseth.

\section{Et sundhedsvæsen i verdensklasse udgør en grundpille i hvert af de nordiske velfærdssamfund}


BOKS 2

\section{Her baner nordiske samarbejder vejen for bedre behandling}

Retinoblastom (en medfødt kræftform i øjet, red.)

Fælles retningslinjer for behandlingen af retinoblastom udvikles under ledelse af S:t Eriks Ögonsjukhus, Sverige.

\section{Rygmarvsskader}

Et fælles nordisk kvalitetsregister for rygmarvsskader er etableret under ledelse af St. Olavs Hospital, Norge.

\section{Børnekirurgi}

Et nordisk netværk for specialister inden for børnekirurgi er etableret under ledelse af Odense Universitetshospital, Danmark.

\section{Småledskirurgi}

En fælles nordisk database om protesekirurgi i skulder, albue, ankel og håndled udvikles under ledelse af Haukeland universitetssjukehus, Norge.

\section{Føtalmedicin}

Et nordisk netværk sikrer fælles uddannelse af specialister i føtalmedicin under ledelse af Rigshospitalet, Danmark.

Tetraplegi (tabt funktionsevne i arme og ben, red.)

Fælles retningslinjer for kirurgiske indgreb i forbindelse med tetraplegi udarbejdes under ledelse Haukeland universitetssjukehus, Norge.

\section{Transseksualisme}

Et nordisk netværk erfaringsudveksler om diagnostik og behandling af transseksuelle, under ledelse af Oslo universitetssykehus, Norge.

Alle syv samarbejder er en del af projektet "Nordisk samarbejde om højt specialiseret behandling" under "Holdbar Nordisk Velfærd". Find det i projektgalleriet på side 62. 


\section{Fra 0 til ti kolleger}

At daglig sparring med kolleger om erfaring, praksis og nyeste viden er afgørende for et sundhedsvæsen i verdensklasse, ved Karin Sundberg alt om. Hun er overlæge på Rigshospitalet i Danmark og specialist i at diagnosticere og behandle fostre, i fagtermer føtalmedicin. Hun har etableret et nordisk netværk på området sammen med sine nordiske kolleger, fordi hun så et behov for mere omfattende deling af viden og erfaring på tværs af landene:

“Jeg synes ikke, vi er skarpe nok på at diagnosticere fostre, som har behov for behandling. Den videndeling, som opstår, når man går op og ned af specialistkolleger hver dag og diskuterer de diagnostiske muligheder, er et vigtigt redskab til at blive bedre," forklarer hun om baggrunden for netværket, som fokuserer på at uddanne specialister i hele Norden i den nyeste viden om arbejdet med at diagnosticere fostre.
I april 2015 afholdt Karin Sundberg og netværket deres første konference for specialister i hele Norden. Det resulterede i flere mindre arbejdsgrupper, som har fortsat videndelingen også efter konferencen. Det er blandt andet noget så simpelt som fælles mailinglister, der hjælper erfaringsudvekslingerne og den uformelle, løbende dialog på vej.

På sigt håber Karin Sundberg på, at den udbyggede specialistuddannelse, som uddanner speciallægerne til at udføre kirurgiske indgreb på fostre, kan blive placeret på nogle få hospitaler:

"Særligt når vi taler kirurgiske indgreb, eksempelvis blodtransfusion på fostre, er der måske kun en enkelt læge i hver region, der kan udføre dem. I Norge eksempelvis gik de to kirurgiske specialister, som fandtes, begge på pension for nogle år siden. Og i Island har de slet ingen. Det er alt for sårbart, og derfor er det sim- pelthen nødvendigt, at vi arbejder sammen om uddannelsen i Norden," forklarer Karin Sundberg, som for nylig havde sin første speciallæge, fra Trondheim i Norge, under vingerne på Rigshospitalet i København.

\section{Samarbejde frem for sammenlægning}

I det hele taget gælder det for Norden, at mange af de højt specialiserede medicinske behandlinger er blevet centraliserede i hvert land. Målet har været at samle ekspertisen for at skabe de stærkeste fagmiljøer.

Med tiden er Hans Petter Aarseth og hans kollegaer i det norske Helsedirektoratet blevet klogere, for i nordisk regi har det vist det sig, at centralisering ikke altid er vejen frem:

"Vi kunne afgjort spare ressourcer snævert set ved at samle behandlingerne. Omvendt må vi erkende, at det ikke er særligt hensigtsmæssigt at bede syge mennesker om at rejse 
langt og oven i købet på tværs af landegrænser for at blive behandlet og måske være væk hjemmefra i rigtig lang tid. Det betyder, at familie og venner er langt væk, og vi ved, at deres støtte er vigtig for, at patienten kommer godt igennem et behandlingsforløb."

I stedet for centralisering peger Hans Petter Aarseth på, at det nordiske samarbejde kan tage mange andre former. Det kan være fælles registre og databaser, fælles retningslinjer for behandlingerne eller kompetenceudvikling og uddannelse.

“De nordiske borgere skal møde kompetent og højt kvalificeret personale, lige meget hvor i Norden de bor. En kortere distance er med til at skabe kvalitet i mødet mellem sundhedsvæsen og borger,” mener han.

\section{Du skal være velkommen!}

Selvom det måske ikke giver mening at bede patienterne rejse på tværs af grænser, ligger der et stort potentiale $\mathrm{i}$ at lade sundhedspersonalet krydse grænserne lidt oftere, er Hans Petter Aarseths erfaring.

“Når vi flyver den bedste ekspertise til patienten, betyder det bedre behandling for den enkelte, og det giver mulighed for, at det faste personale kan lære af de specialister, vi henter ind," fortæller han.

Det giver god mening i Karin Sundbergs optik. Hun ønsker sig et korps af specialiserede læger inden for føtalmedicin, som kan flyve rundt til behandlinger i hele Norden. Og det er hun ikke alene om.

Generelt står det at indhente det bedst kvalificerede personale højt på ønskelisten mange steder i de nordiske sundhedsvæsner - både for at blive bedre til at samarbejde på højt specialiserede områder, og fordi den demografiske udvikling generelt kræver mere og bedre sund- hedspersonale. I fremtiden kommer der flere og hyppigere gæster i de nordiske sundhedsvæsener, bl.a. fordi vi bliver ældre og ældre. Til gengæld bliver der færre borgere i den erhvervsaktive alder til at betale omkostningerne. Se figur 5 på side 15 .

Heldigvis giver både EU-lovgivning og nordiske overenskomster gode muligheder for, at velfærdspersonale i Norden kan tage arbejde dér, hvor deres faglige interesse eller personlige liv fører dem hen. Det viser rapporten Arbejdsmarkedsmobilitet i Norden - Lovregulerede erhverv og velfærdsprofessioner, som er udarbejdet under "Holdbar Nordisk Velfærd" af det danske konsulenthus Damvad. Find den i boks 3.

Tallene viser, at langt de fleste ansøgere uddannet i et nordisk land, som ønsker at arbejde permanent i et andet nordisk land, får et positivt svar. I dag bor ca. 425.000 personer 


\section{BOKS 4}

\section{Velfærdsuddannelser i udvikling}

Fremtidens velfærdssamfund har brug for flere hænder. Så simpel er konklusionen i flere af de rapporter, som er udarbejdet under "Holdbar Nordisk Velfærd".

svarende til 3,3\% af den samlede nordiske arbejdsstyrke i et andet nordisk land end det, de er født i.

Det er gode nyheder på den korte bane, konkluderer Damvad i rapporten. Én måde at sikre arbejdskraft i de nordiske sundhedsvæsner på i fremtiden er nemlig at rekruttere fra hinanden landene imellem. På lang sigt er udfordringen med at finde flere hænder i de nordiske sundhedsvæsner dog ikke løst med det. Selvom udvekslingen af arbejdskraft kan udjævne ubalancer på kort sigt, viser de demografiske fremskrivninger med al tydelighed, at der også er brug for at uddanne flere. For at regnestykket mellem patienter og personale skal gå op i sidste ende, er uddannelsernes attraktivitet derfor også et vigtigt indsatsområde, vurderer Damvad. Læs mere om, hvordan de nordiske lande kan arbejde sammen om at geare velfærdsuddannelserne til den udfordring, i boks 4 .
Løsningerne er flere. Trond Nygaard, seniorrådgiver i Helse- og omsorgsdepartementet i Norge, peger i rapporten Recruitment and Retention of Health Care Professionals in the Nordic Countries på, at de nordiske lande bør arbejde med at gøre uddannelserne mere attraktive, så flere unge søger ind og også fuldfører uddannelsen. Find rapporten i boks 7 .

En anden løsning handler om at sørge for, at de mennesker, som tager en velfærdsuddannelse, er klædt bedst muligt på til at møde fremtidige udfordringer. Det handler bl.a. om at give de nordiske velfærdsuddannelser et løft, så vi sikrer, at de inddrager den nyeste viden i undervisningen, vurderer Marianne Aastebøl Minge, seniorrådgiver i NordForsk (en nordisk rådgivnings- og finansieringsorganisation for forskning, red.).

De sidste tre år har hun og NordForsk i samarbejde med det danske konsulenthus Damvad og det svenske konsulenthus Faugert \& Co. nærstuderet koblingerne mellem forskning og velfærdsuddannelser på tværs af de nordiske lande.

Konklusionen af deres analyse er, at selvom forskellige systemer umuliggør en one size fits all-model, så har de nordiske lande forskellige fokusområder i deres forskning, som gør, at det er en god idé at tænke på tværs af grænserne, eksempelvis ved at lave fælles nordiske initiativer, som styrker velfærdsuddannelsernes forskningsmæssige forankring.

“Får vi en stærkere kombination af forskning og uddannelse, har vi på sigt nøglen til at udvikle nye servicer, til at effektivisere og til at optimere kvaliteten for borgerne," forklarer hun.

Netop den forskningsmæssige forankring er i fokus, når en ny nordisk master i velfærd ser dagens lys i 2016. "Nordic Master in Social Work and Welfare" er oprettet som et samarbejde mellem Stavanger Universitet i Norge, Aalborg Universitet i Danmark og Umeå Universitet i Sverige. De studerende på uddannelsen skal tage fag på mindst to af de tre universiteter i løbet af de to år. Første hold starter i efteråret 2017.

Projekterne "Rekruttering og fastholdelse af ansatte i plejesektoren", "Velfærdsprofessioner i Norden" og "Nordisk master inden for velfærd" er alle en del af "Holdbar Nordisk Velfærd". Find dem i projektgalleriet på side 62. 


\section{Mit håb er, at vi om ti år er kommet længere med at skabe en kultur for samarbejde i Norden.}

\section{Langsom opstart}

Selvom fordelene ved at samarbejde kan virke indlysende, er det ikke nødvendigvis nemt i en travl hverdag. Det ved Annette Halvorsen, som er overlæge på afdelingen for rygmarvsskader på St. Olavs Hospital i Norge. Mens man i Norge registrerede 419 nye rygmarvsskader i perioden 2011-2014, var tallet i samme periode i hele Norden, ifølge Nordisk Ministerråds oplysninger, meget højere, omkring 4.000 tilfælde. Endnu bliver tilfældene på tværs af landene ikke registreret i et fælles medicinsk register, og det er ærgerligt. Blandt andet, fordi flere patienter giver et bedre grundlag for at finde sammenhænge mellem rygmarvsskaderne og eventuelle komplikationer senere i patienternes liv. For at bane vejen for ny viden og på sigt også bedre behandling har Annette Halvorsen og hendes kollega Ann Louise Pettersen, som er sygeplejerske på St. Olavs Hospital, siden 2013 arbejdet på at etablere et fælles nordisk register for personer med rygmarvsskader.
Efter planen er registeret færdigt i 2016, og sundhedspersonale på ni behandlingssteder i Danmark, Norge, Island og Finland kan begynde at registrere data i det samme system.

Selvom Annette Halvorsens oplevelse er, at registeret imødekommer et stort ønske på tværs af fagmiljøerne i Norden, er hendes erfaring ikke desto mindre, at dialogen med kollegaerne i de andre lande alligevel tager tid:

“Vores samtaler med hospitaler på tværs af landene har taget enormt lang tid. Ikke fordi vi har oplevet modvilje, men fordi det at finde frem til vores fælles behov kræver, at vi taler sammen flere gange, og det er sjældent, at fem minutter over telefonen er nok. 'Rigtige' samtaler er helt afgørende, fordi alle skal kunne se meningen med registeret, ellers bruger de det ikke," forklarer Annette Halvorsen, som sammen med sin kollega Ann Louise Pettersen har rejst rundt og talt med kollegerne i de andre nordiske lande for at få alle med på at lave registeret.
Selvom det er en tidskrævende øvelse, er Ann Louise Pettersens erfaring, at det godt kan betale sig at rejse rundt mellem landene, når man har fælles anliggender at tale om. Det hjælper nemlig både tilliden og det fælles engagement på vej at mødes ansigt til ansigt:

“Én ting er at snakke i telefon eller via mail, men det giver altså noget ekstra, når man sidder over for hinanden ansigt til ansigt. Jeg prioriterer at mødes, fordi jeg oplever, at det styrker den fælles ansvarsfølelse for registeret, at vi har sat ansigt på hinanden og drukket en kop kaffe sammen. Det giver en fornemmelse af, at vi er sammen om projektet," fortæller hun.

\section{Lokal forankring}

Hans Petter Aarseths erfaring er også, at samarbejdet på de højt specialiserede områder faktisk er hårdt arbejde. Han fremhæver ligesom Annette Halvorsen og Ann Louise Pettersen det lokale ejerskab som særligt vigtigt. Det skaber nemlig den bedste grobund for samarbejder, der varer ved. 


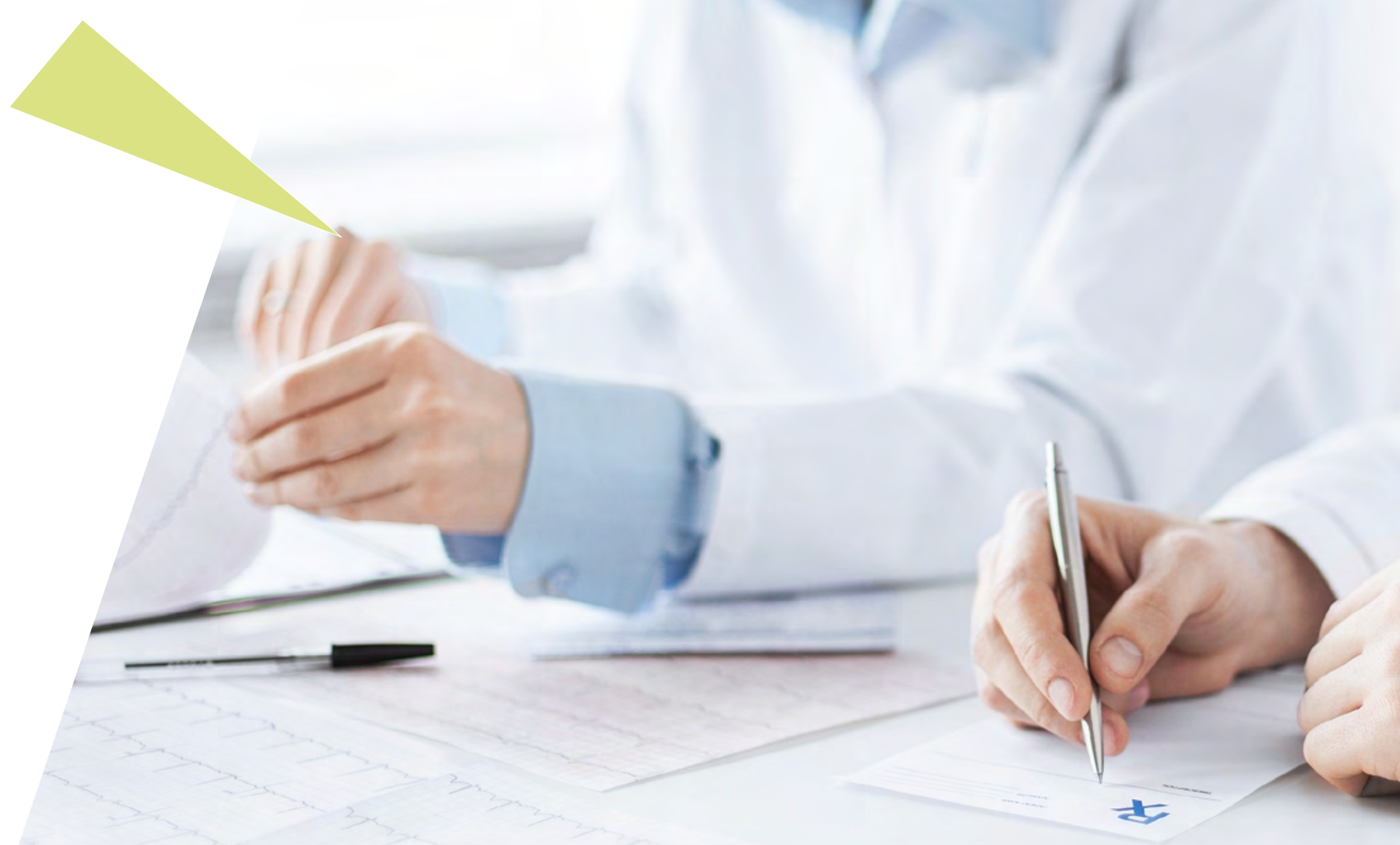


“Fra centralt hold kan det være svært at holde samarbejder i live, når projektperioden udløber. Det handler blandt andet om, at det er ledelsen på det enkelte hospital, som skal blåstemple det tidsforbrug, personalet lægger i samarbejdet. Derfor kommer vi også til at indgå lokale aftaler med både St. Olavs og Rigshospitalet, som har forpligtet sig på at prioritere initiativerne - også på sigt," fortæller Hans Petter Aarseth.

\section{Af samme grund er de syv samar-} bejdsprojekter heller ikke vilkårligt placeret. Den lokale forankring kan nemlig ikke gennemtvinges, er hans erfaring.
"I stedet for at opfinde nye samarbejder, har vi bestræbt os på at dyrke de ønsker og idéer, som allerede var til stede på hospitalerne i Norden. På den måde har vi fået forankret projekterne på de hospitaler, hvor gejsten, ekspertisen eller erfaringerne var særligt gode. Eksempelvis er rygmarvsregisteret forankret på St. Olavs Hospital, som i forvejen har arbejdet med etableringen af det norske register i 5 år."

Perspektiverne i at understøtte ildsjælene på de nordiske hospitaler er Hans Petter Aarseth i øvrigt ikke i tvivl om. Han håber på, at flere læger og mere sundhedspersonale kaster sig ud i samarbejdet i fremtiden:
“Mit håb er, at vi om ti år er kommet længere med at skabe en kultur for samarbejde i Norden. Hvis man som specialist i Finland vil etablere et netværk omkring et eller andet, så skal man kunne gøre det. Sådanne bottom-up-samarbejder rummer store potentialer, hvis vi fra systemets side bestræber os på at give plads til dem, eksempelvis via økonomisk støtte eller sparring på organiseringen," fortæller han. 

I den danske by Odense er der flyttet robotstøvsugere ind på byens 28 plejecentre og hjemme hos flere og flere ældre borgere. Robotstøvsugerne erstatter til en vis grad den traditionelle støvsugning, og det betyder meget både for økonomien og for den enkelte borger, fortæller Rikke Falgreen Mortensen, som er specialkonsulent i Center for Velfærdsteknologi i Odense Kommune:

"Robotterne betyder, at kommunens medarbejdere kan bruge tiden på noget andet end at støvsuge. $\mathrm{Og}$ for den enkelte borger betyder det, at de selv kan bestemme, hvornår det passer i hverdagen at støvsuge, frem for at lade det være op til vores vagtplaner. Det giver livsglæde at have større kontrol over eget liv," fortæller hun.
Ambitioner om effektivisering og om at give hjælp til selvhjælp har drevet Odense Kommunes arbejde med velfærdsteknologi det seneste årti og gjort kommunen til en af de førende i Norden. Resultatet af indsatsen er indtil videre 14 fuldt implementerede teknologier, som ud over robotstøvsugere tæller alt fra stemmestyrede døråbningssystemer til automatiske vendemadrasser. Og mange flere er på vej.

Brugen af velfærdsteknologi i Odense Kommune demonstrerer nogle af de potentialer, teknologien tilbyder, når det drejer sig om at skabe bedre velfærd. Det gælder i Danmark som i resten af Norden, hvor sundhedsog plejesektorerne kæmper med at få regnestykket med flere ældre og færre hænder til at gå op. Læs mere om potentialerne i teknologierne $\mathrm{i}$ boks 5 .
Men i realiteten fylder velfærdsteknologien desværre mere i tale end $i$ handling $i$ langt de fleste af Nordens kommuner, mener Dennis Søndergård, som er seniorrådgiver i Nordens Velfærdscenter og arbejder med at udbrede brugen af velfærdsteknologi på tværs af grænserne i Norden.

Blandt samarbejdspartnerne er ti af Nordens førende kommuner inden for velfærdsteknologi, herunder Odense, som er gået sammen med Nordens Velfærdscenter om at udvikle en model for arbejdet med teknologi i kommunerne. Samarbejdet går under navnet "CONNECT", og målet er at inspirere mange flere af Nordens 1.200 kommuner til at komme fra tale til handling.

\section{Robotterne betyder, at kommunens medarbejdere kan bruge tiden på noget andet end at støvsuge.}


BOKS 5

\section{Velfærdsteknologi - hvorfor?}

\section{$\varnothing$ konomiske gevinster}

I perioden 2014-15 har indførelsen af velfærdsteknologier på ældre- og handicapområdet i Danmark frigjort 233,3 mio. DKK. Frem mod 2017 vurderer Kommunernes Landsforening i Danmark (KL), at udbredelsen af velfærdsteknologier i danske kommuner kan frigøre i alt 500 mio. DKK.

\section{Menneskelige gevinster}

Over halvdelen af de danske kommuner oplever, at deres arbejde med velfærdsteknologi giver gevinster for både borgere og personale. De hyppigst oplevede gevinster for borgerne er større selvstændighed, tryghed i hverdagen samt aflastning af ægtefæller og pårørende. For medarbejderne fremhæver kommunerne særligt, at teknologierne skaber forbedret arbejdsmiljø og bedre arbejdsstillinger samt større fleksibilitet i hverdagens opgaveløsninger.

Kilde: Det fælleskommunale program for udbredelse af velfærdsteknologi, Kommunernes Landsforening i Danmark (KL), 2015.

Note: Undersøgelsen omhandler forflytningsteknologi, vasketoiletter og spiserobotter. 90 ud af Danmarks 92 kommuner har deltaget $i$ undersøgelsen.
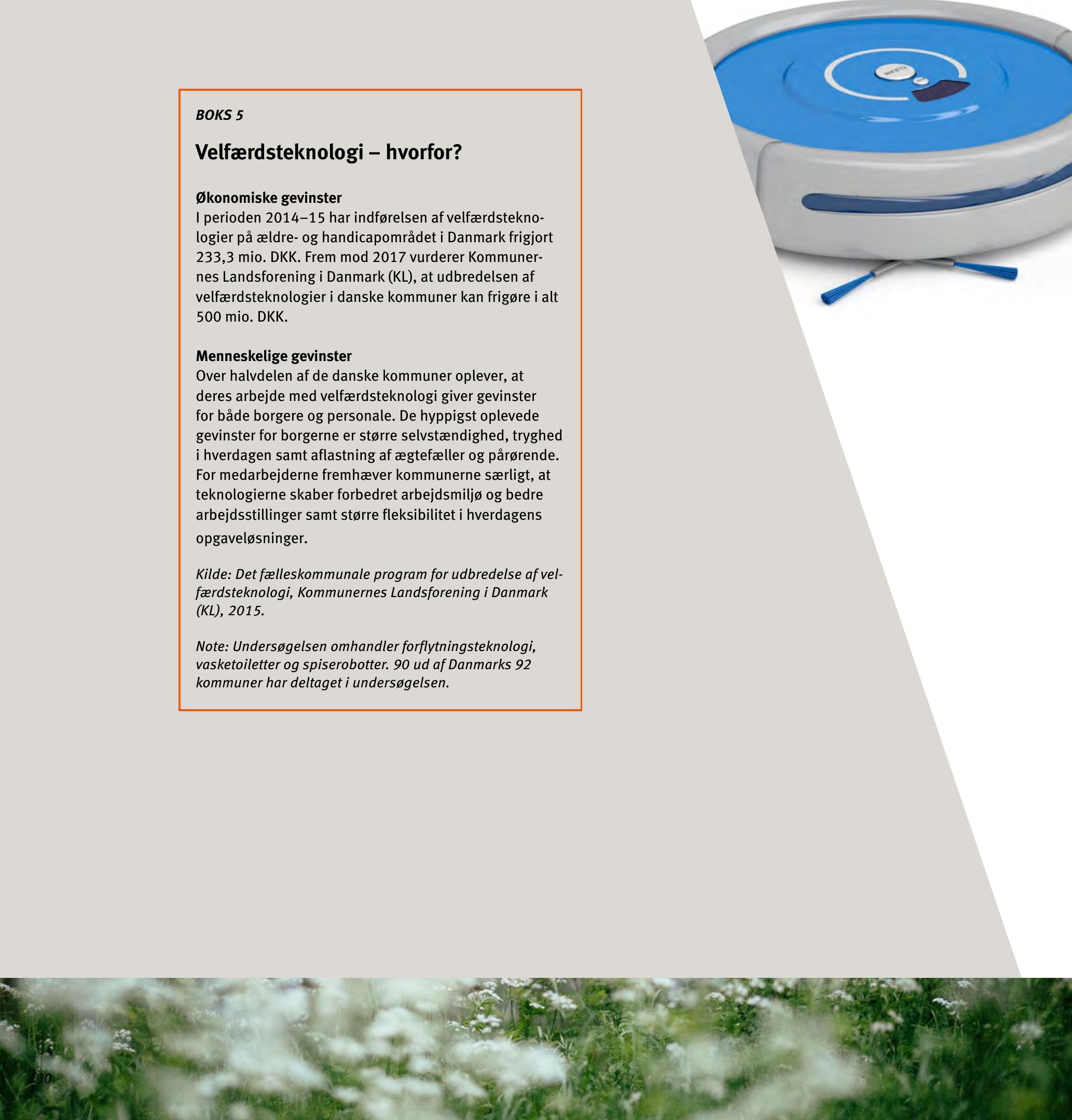
De forskellige tilgange til teknologierne har givet anledning til både øjenåbnere og ahaoplevelser for kommunerne i netværket.

“Jeg blev mildest talt overrasket over den svenske tilgang til teknologi, som er baseret mere på at skabe tryghed, eksempelvis for ældre i eget hjem. Det har ikke fyldt i samme omfang i Danmark eller i Odense Kommune. Nu tænker jeg, at selvfølgelig skal vi også fokusere på, hvordan teknologierne kan andet og mere end at effektivisere og rehabilitere," fortæller Rikke Falgreen Mortensen fra Odense Kommune.

Det er Mats Rundkvist, som er Rikke Falgreen Mortensens inspirationskilde. Han fremhæver omvendt, at Rikke Falgreen Mortensen og Odense Kommune har leveret inspiration den anden vej, når det handler om at evaluere teknologierne på, om de giver økonomisk gevinst.

Det er i de forskellige perspektiver på teknologierne, at potentialet i samarbejde over grænserne opstår, mener Dennis Søndergård.

"Vores forståelse af velfærdsteknologi skal rumme både økonomiske og kvalitative aspekter og alle nuancerne ind imellem. Min oplevelse er, at den nordiske samtale kan give os et mere solidt fundament at tale om velfærdsteknologi på, fordi vi bliver skarpere på de mange forskellige måder, som teknologierne kan bidrage til velfærden på," forklarer han og uddyber:

"Velfærdsteknologi skal både handle om at frigive hænder, om at skabe tryghed og om at hjælpe borgere til at hjælpe sig selv.”

Se eksempler på, hvordan de nordiske lande har forskellige styrker i boks 6 .

\section{En del af et paradigmeskifte}

Desværre rimer teknologierne for mange mennesker stadig mere på forringelser end på kvalitet. Det gælder generelt i Norden, og det er også
Jaana Kokkos erfaring. Hun er teknologisk specialist i Oulu Kommune, Finland, og medlem i "CONNECT". Hun mener, at der endnu ligger et arbejde $\mathrm{i}$ at formidle både de økonomiske og de kvalitative potentialer $i$ de nye teknologier:

“Folk er bekymrede for, at menneskelig kontakt bliver erstattet af robotter. Det er selvfølgelig ikke målsætningen. Målet er, at teknologien supplerer de velfærdsprofessionelles arbejde, sådan at de kan udføre deres arbejde smartere. Det handler både om at frigive tid til personalet og om at sikre bedre pleje til borgerne," forklarer hun.

I stedet for at køre de velfærdsprofessionelle ud på et sidespor, oplever Jaana Kokko, at arbejdet med teknologi understøtter den nye måde at tænke pleje på, der i disse år gør sit indtog i de nordiske lande. Hjælp til selvhjælp eller rehabilitering, som det er kommet til at hedde i fagsprog, handler om, at borgeren skal klare sig selv længst muligt, og 
ISLAND

Reykjavik Kommune og Akureyri Kommune:

Copy-paste og

skalering

af teknologi

\section{BOKS 6}

\section{Hvert land sin styrke}

De ti nordiske kommuner i "CONNECT" har haft forskellige fokusområder i deres arbejde med teknologi, og det skaber grobund for at udvikle en best practice-model, som inddrager erfaringer fra alle de nordiske lande.

Mens Danmark eksempelvis er langt inden for evaluering, er Finland stærk inden for "procurement", som handler om at udvikle produkter i samarbejde med virksomheder, og Sverige er førende udi at involvere borgerne i udvikling af løsningerne. Grafikken viser, hvilke kommuner der er med i netværket, og hvad de hver især er særligt gode til.

\section{DANMARK}

Odense Kommune og Aarhus Kommune:

Evaluering og gevinstrealisering

\section{FINLAND}

Oulu Kommune og Sydkarelia:

Procurement

(udvikling af produkter

i samarbejde med

Lister-regionen:

Udvikling af teknologi

i kommunale

samarbejder

\section{SVERIGE}

Västerås Stad

og Göteborg Stad:

Borgerinddragelse 
at velfærdspersonalets fornemste opgave er at træne borgeren til at kunne selv frem for at gøre tingene for vedkommende. Det kan fx handle om genoptræning efter et slagtilfælde, så borgeren igen selv kan købe ind eller gå på nabobesøg. Eller om at få hjælpemidler installeret $\mathrm{i}$ sin bolig, så man selv kan klare fx toiletbesøg.

Den rehabiliterende tilgang blev introduceret i Sverige omkring årtusindskiftet, bredte sig til Danmark i årene efter og ramte til sidst resten af de nordiske lande. Det fortæller Trond Nygaard, som er seniorrådgiver i Helse- og omsorgsdepartementet i Norge. I 2013 udarbejde han i samarbejde med det danske konsulenthus Damvad en analyse af de nordiske plejesektorer for at kortlægge udfordringer og muligheder med rekruttering og fastholdelse af personale i fremtiden. Find rapporten i boks 7 .

"Jeg mener, at der er tale om et paradigmeskifte i hele Norden, hvor vi i stedet for at tænke i pleje og hjælp i stigende grad tænker i hjælp til selvhjælp. Dén faglige omlægning handler fx om at hjælpe flere og flere ældre til at blive boende længere i eget hjem, og om at tænke i mestringsstrategier, dvs. måder at hjælpe borgere til at kunne klare flere ting selv," forklarer han og understreger, at det selvfølgelig ikke handler om, at de, som har brug for pleje, ikke skal have det.

Potentialerne i paradigmeskiftet er store, fremhæver Trond Nygaard. Særligt fordi alle de nordiske lande i de kommende årtier skal tage sig af historisk mange ældre medborgere og derfor kan drage stor nytte af de nye teknologier. Det handler med andre ord om, at vi gør tingene bedre - og smartere i fremtiden. Læs mere om den demografisk udvikling på side 15 .

Boks 7

Læs mere om rehabilitering i Norden

Recruitment and Retention of Health Care Professionals in the Nordic Countries 
Derfor er det også vigtigt altid at holde sig målet for øje, når man taler om velfærdsteknologi, mener Mats Rundkvist fra Västerås Kommune i Sverige:

“Teknologier er midler. De er ikke mål i sig selv, men vigtige redskaber i udviklingen lige nu. Om ti år håber jeg, at vi taler mindre om teknologi og mere om omsorg. For det er det, det handler om. At vi også i fremtiden kan tage os af vores ældre på en værdig måde - uanset antallet," fortæller han.

\section{Best practice-model samler styrkerne}

Endnu er der langt igen, før velfærdsteknologi bliver hverdag i alle de nordiske kommuner, erkender Dennis Søndergård. Derfor er ambitionen med "CONNECT"-projektet at udarbejde en best practice-model, som skal gøre det let at komme fra idé til implementering i de nordiske kommuner. Hvis arbejdet med teknologierne skal forankres i kommunerne, kræver det nemlig systematik, oplever han:

"Mange af de nordiske kommuner er ramt af det, man kunne kalde for 'akut projektitis', hvor velfærdsteknologierne aldrig bliver en del af driften. Vi er simpelthen ikke gode nok til at implementere vores idéer. Ikke fordi alle idéer skal implementeres, men fordi vi i det mindste skal evaluere dem og sørge for at lære af vores erfaringer," forklarer Dennis Søndergård.

Kommer flere kommuner med på vognen, vil det også gøre det lettere at finde private virksomheder, som kan se en gevinst $i$ at samarbejde med kommunerne om at udvikle de nye løsninger, fortæller Mats Rundkvist fra Västerås Kommune. På sigt håber han på et stærkt nordisk marked for velfærdsteknologi:

“Hvis flere kommuner tænker teknologierne ind i deres drift, så får markedet en energiindsprøjtning, simpelthen fordi gevinsten for de virksomheder, som laver velfærdsteknologi, bliver større, hvis flere kommuner er interesserede $i$ at købe løsningerne. Forhåbentlig vil det også motivere virksomhederne til at udvikle endnu flere nye løsninger i fremtiden," siger han.

Teknologier er midler. De er ikke mål i sig selv, men vigtige redskaber i udviklingen lige nu. 


\title{
Det giver også mening at samarbejde ...
}

\author{
... når vi ikke ved nok om os selv
}

"Vi ved for lidt om, hvordan globale og omfattende kriser påvirker vores borgere. Velfærdsvagten blev sat i gang under finanskrisen i Island for at indsamle data, fx om hvor mange der mistede deres job eller bolig. På den måde har vi forhåbentligt et bedre overblik, når den næste krise rammer, fordi vi ved, hvordan og hvem den rammer hårdest. Det handler om at geare os bedre til at håndtere kriser, og den udfordring gælder for alle nordiske lande - også fordi vi kan lære noget af, hvorfor krisen ramte os forskelligt.”

Guðrún Sigurjónsdóttir, konstitueret vicedirektør, Velfærdsministeriet, Island.

Læs mere om arbejdet med at udvikle en nordisk "velfærdsvagt" her.

\section{... når vi skal tænke nyt}

"Vores børn skal blive bedre til at tænke nyt, se muligheder og omsætte idéer til handling - det skal de bl.a. lære i skolen. Men lige nu uddanner vi lønmodtagere til industrisamfundet. Det dur ikke, for vi lærer eleverne det, vi allerede ved. Vi skal lære dem at tænke nyt, så de kan stille spørgsmål til de systemer, vi har bygget op, og gøre dem bedre - det er afgørende for fremtidens velfærd."

Helle Munkholm Davidsen, forskningsleder, University College Lillebælt, Danmark, og deltager $i$ workshoppen ‘Entreprenørskab i grundskolen', København, maj 2015.

Læs mere om, hvordan skoler i Norden arbejder med entreprenørskab i Når jeg bliver stor.

\section{... når vi ikke lykkes}

“På tværs af Norden lever alt for mange mennesker i det, vi kalder 'udenforskab', fordi de aldrig har fået fodfæste på arbejdsmarkedet. Sociale entreprenører bidrager med at finde nye løsninger på disse og andre sociale udfordringer. Vi skal blive bedre til at samarbejde om den opgave offentlige, private og frivillige aktører imellem, og særligt skal vi blive bedre til at involvere de mennesker, det drejer sig om, i løsningerne."

Aase Lunde, seniorrådgiver, Arbeids- og sosialdepartementet, Norge.

Læs mere om, hvordan de nordiske lande arbejder med socialt entreprenørskab, og find seks anbefalinger til, hvordan vi bliver bedre her.

Alle tre projekter er en del af "Holdbar Nordisk Velfærd". Find dem i projektgalleriet på side 62. 



\section{Hvordan får vi flere unge til at gennemføre en erhvervs- uddannelse?}

Det spørgsmål stiller Margaretha Allen, uddannelsesdirektør i det svenske Skolverket, sig selv og sine nordiske kolleger i en tid, hvor alle de nordiske lande kæmper med betydelige frafald på erhvervsuddannelserne og høj ungdomsarbejdsløshed. Se figur 8 og 9 .
Situationen er problematisk - ikke kun for den enkelte unge, som risikerer ikke at få fodfæste på arbejdsmarkedet, men også for virksomhederne i de nordiske lande, som har brug for dygtige faglærte. Mennesker, der både kan bruge hoved og hænder. Derfor har Margaretha Allen taget initiativ til det nordiske netværk "Læring på arbejdspladsen", som samler erhvervsskoler, brancheorganisationer, virksomheder og nationale myndigheder på tværs af de nordiske lande. Formålet er sammen at sætte samspillet mellem uddannelser og arbejdsmarked på dagsordenen. Margaretha Allen er ikke i tvivl om, at de nordiske lande har meget at lære af hinanden i den forbindelse:

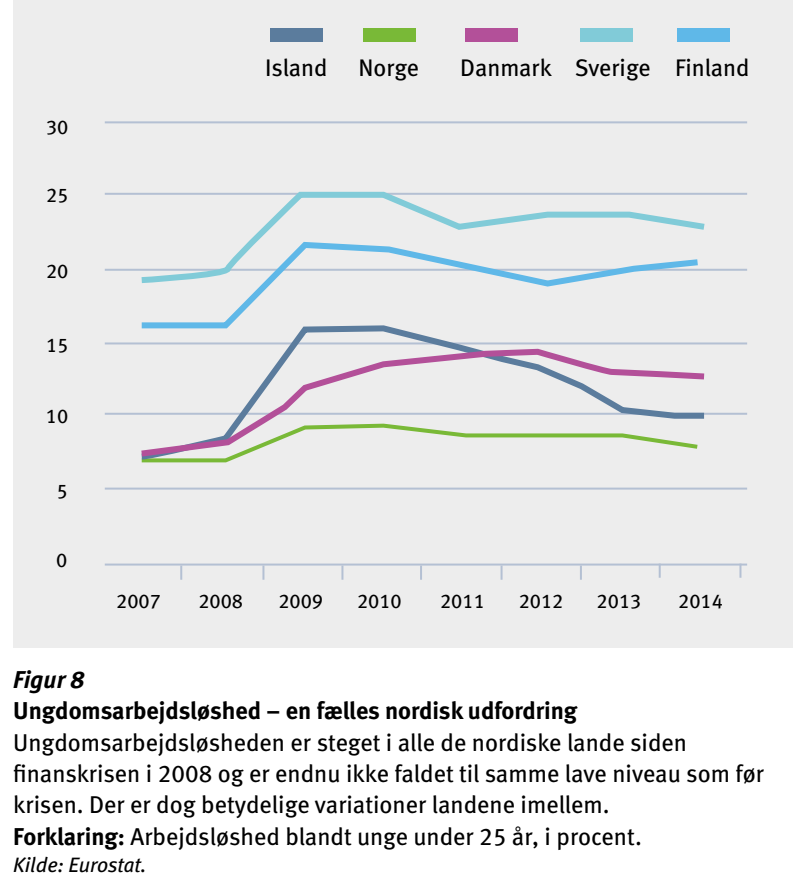

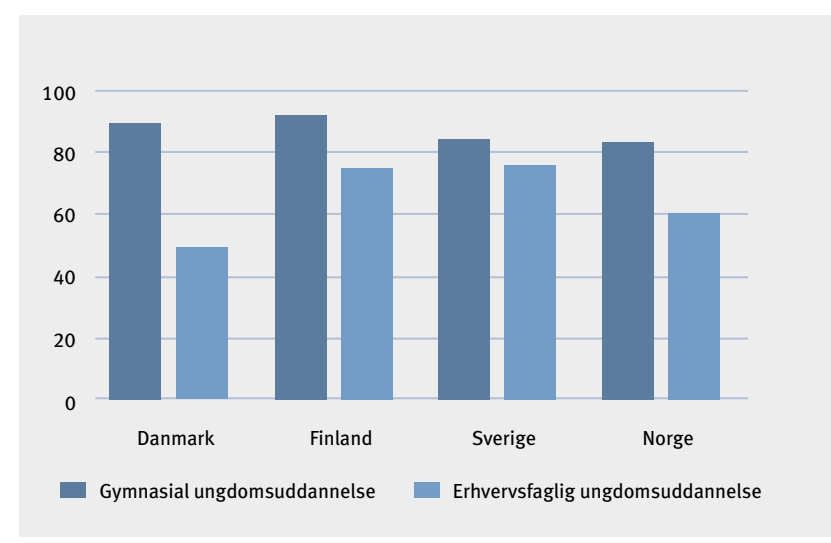

Figur 9

For få gennemfører en erhvervsuddannelse

I alle de nordiske lande er der større frafald blandt studerende på de erhvervsfaglige ungdomsuddannelser end blandt studerende på de gymnasiale ungdomsuddannelser.

Forklaring: Andelen af studerende som færdiggør uddannelserne på normeret tid eller inden for to år efter uddannelsens normerede længde, i procent. Data for Island mangler.

Kilde: Education at a Glance, OECD, 2014. 
"Vi har samme kulturelle baggrund i Norden, og alligevel har vi udviklet vidt forskellige systemer på erhvervsskoleområdet. Hvorfor gør nogen, der ligner os så meget, noget helt andet end vi selv? Det har vi lejlighed til at undre os over og diskutere $\mathrm{i}$ netværket. Det handler ikke kun om at lade sig inspirere af hinanden, men også om at blive klogere på os selv og om at se vores eget uddannelsessystems styrker og svagheder med andre øjne," fortæller hun om tankerne bag netværket, som siden 2013 har turneret de nordiske lande til ti netværksmøder om udfordringer og løsninger.

\section{Inspiration frem for 1:1-implementering}

Forskellene mellem landenes uddannelsessystemer og -traditioner viser sig eksempelvis, når man sammenligner Sverige med de øvrige nordiske lande.

I Sverige er det staten, der fastlægger indholdet i erhvervsuddannelserne, og uddannelserne er skolernes ansvar alene. I de andre nordiske lande er der omvendt en lang tradition for at inddrage arbejdsmarkedets parter tæt i udviklingen af erhvervsuddannelsernes indhold, både nationalt og lokalt. Ansvaret for eksempelvis praktikforløb er derfor også lagt ud til de enkelte skoler og virksomheder.

"Vi har forskellige traditioner, ja. Derfor er det let at tro, at man i Finland ikke kan lære så meget af Sverige, men så enkelt er det ikke. Sverige kan jo have opnået noget andet, som man kan lade sig inspirere af i Finland, uden at man nødvendigvis skal kopiere hele skolesystemet 1:1," fortæller Margaretha Allen.

\section{Et eksempel på et sådant initiativ er} "Teknikcollege" i Sverige. Initiativet er et samarbejde mellem kommuner, uddannelsesinstitutioner og arbejdsgivere, der skal være med til at sikre lokale og regionale arbejdsgivere kvalificeret arbejdskraft i fremtiden ved at matche uddannelsesplaner med virksomhedernes behov.

Samarbejdet er startet op uden indblanding fra staten, fordi både skoler og virksomheder så et behov. Selvom der ikke er samme tradition for inddragelse af arbejdsmarkedets parter i Sverige, kan man altså godt finde eksempler på mindre og lokale initiativer, der bygger bro. For Margaretha Allen er det netop den slags eksempler, som bekræfter, at vi skal spadestikket dybere, hvis vi for alvor vil lære af hinanden.

"Vores samtaler i netværket har aldrig handlet om at finde én rigtig systemløsning, som kan fungere i hele Norden. I stedet handler det om at finde de inspirationskilder, som gør, at man kan gå hjem og gøre noget anderledes allerede i morgen," forklarer hun.

Teknikcollege er bare et eksempel på, hvor de nordiske lande kan lære af hinanden, vurderer Johanna Enberg, som er konsulent hos det svenske konsulentfirma Faugert \& Co. I 2014 kortlagde hun i rapporten Rekrytering, genomströmning och relevans - en studie av yrkes- och lärlingsutbildningssystemen i Norden de nordiske landes indsatser for at bygge bro mellem uddannelser og arbejdsmarked, og hendes konklusion er ligesom Margaretha Allens, at der er masser af inspiration at hente, hvis vi ikke går 


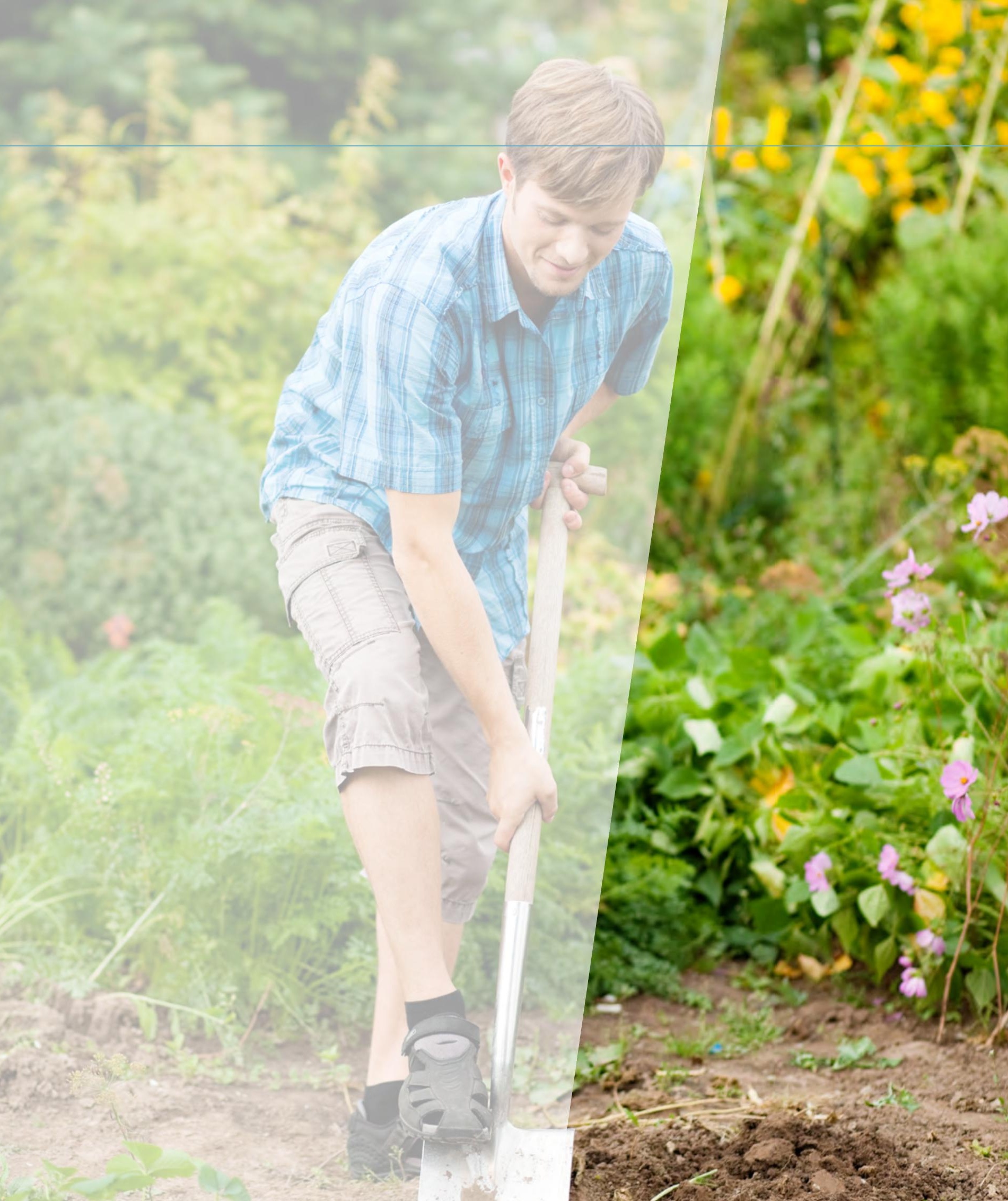




\section{BOKS 8}

Læs mere om de nordiske erhvervsskole-systemer

Rekrytering, genomströmning och relevans - en studie av yrkes- och lärlingsutbildnings-systemen i Norden

efter at kopiere systemløsninger 1:1, men i stedet indstiller blikket anderledes:

“Ofte er der mindre initiativer eller dele af et system, som sagtens lader sig overføre fra et land til et andet, selvom vi har indrettet vores uddannelsessystemer forskelligt. I alle de nordiske lande er der gode eksempler på brobygningsinitiativer, dvs. tiltag, som støtter overgangen mellem uddannelse og arbejdsmarked. Det er hér, vi kan lære af hinanden og lade det, der virker et sted, inspirere indsatserne andre steder," forklarer hun.

Find rapporten i boks 8, og læs mere om nogle af de initiativer, som Faugert og Co. fremhæver som mulige inspirationskilder for erhvervsskoler, myndigheder og arbejdsgivere på tværs af Norden i boks 9.

\section{Når mennesker mødes frem for død videndeling}

Deltagerne i netværket er mødtes ti gange de sidste tre år, og tiden har været godt givet ud, er Margaretha Allens vurdering. Hendes erfaring er, at mange endnu tænker, at tilgængelig viden er nøglen til læring på tværs. Men udfordringen med tunge rapporter er imidlertid, at det langt fra altid lykkes dem at lære fra sig. Selvom ny viden er vigtig, er det i Margaretha Allens optik mindst lige så vigtigt, at vi bruger tid på at tale om den og sætte den i perspektiv.

“Det er vigtigt at fremhæve, at når vi taler samarbejde på tværs af Norden, så kan en rapport ikke gøre det alene. Det gælder især, når de fælles udfordringer ikke entydigt kalder på ens løsninger, som bare kan implementeres. Oftest er det, der er brug for, dialog, hvor vi kan blive klogere på os selv og hinanden," forklarer hun.

Det genkender Helen Gray, udviklingsdirektør i Center for Livslang Læring på erhvervsuddannelsescenteret IDAN i Island. Hun har læst adskillige kortlægninger af de forskellige systemer i de nordiske lande for at blive klogere og finde inspiration. Ikke desto mindre har samtalerne de sidste to år givet hende anledning til at se nye sider af systemer, hun troede, hun kendte:

“Når man taler med folk, får man blik for den uformelle side af systemet. For nylig var vi fx på besøg på en skole i Göteborg i Sverige, fordi de laver et interessant projekt om at integrere logbøger på arbejdspladsen (bøger, hvori studerende under deres praktikophold kan reflektere over læring, læringsmål og sammenhæng mellem opgaver og pensum, red.). Det besøg kom kun i stand, fordi jeg talte med svenskerne i netværket 'Læring på arbejdspladsen' om det. På den måde er det ofte ad omveje, at man finder de mindre inspirationskilder, som ikke desto mindre er vigtige," fortæller hun.

Netop derfor har Margaretha Allen også forsøgt at holde fokus på samtalen i netværket "Læring på arbejdspladsen".

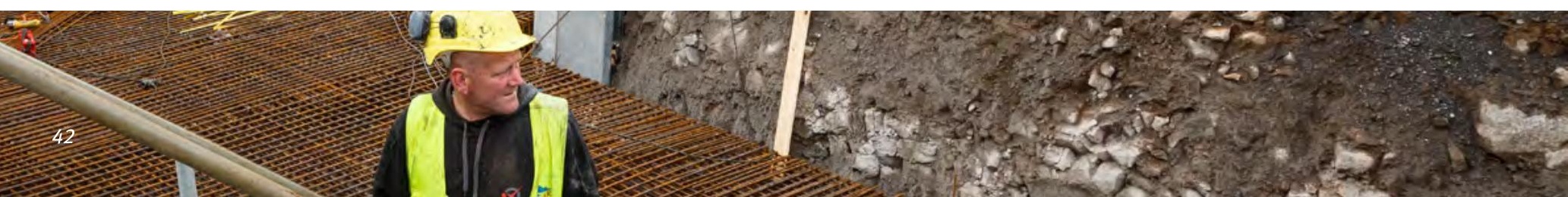




\section{Stærkere erhvervsuddannelser i Norden - her kan vi lære af hinanden}

\section{Centre for Livslang Læring i Island}

I Island er det lykkedes at hjælpe flere voksne til at gennemføre en erhvervsuddannelse ved at samle alt, hvad voksne har brug for i forbindelse med deres erhvervsuddannelse, i regionale Centre for Livslang Læring. Centrene tilbyder eksempelvis karriererådgivning, kompetencevurdering, kurser i islandsk for udlændinge samt mulighed for fjernundervisning.

\section{Kvalitetssikringssystemer i Norge}

For at øge kvaliteten i erhvervsuddannelserne har Norge med gode resultater etableret et nationalt kvalitetsvurderingssystem for erhvervsskolerne. Systemet inddrager lokale parter i diskussionen om kvalitet i stedet for at være kontrolleret af nationalt fastsatte standarder. Systemet bliver derfor også brugt lokalt på skolerne til at inddrage arbejdsgivere, undervisere og studerende i, hvordan uddannelserne skal indrettes.

\section{Teknikcollege i Sverige}

I Sverige har man gode erfaringer med at matche erhvervsuddannelsernes undervisning med virksomheders behov i initiativet "Teknikcollege", som Industrirådet står bag. "Teknikcollege" er en certificering, som erhvervsskolerne kan få, hvis de integrerer løbende dialog og samarbejde med lokale virksomheder i skolens undervisning og arbejde med at finde praktikpladser.

\section{Kvalitetspatruljen i Danmark}

I et treårigt projekt fra 2010-13 arbejdede de danske erhvervsuddannelser og Ministeriet for Børn og Unge sammen om at højne kvaliteten i uddannelserne, blandt andet via erfaringsudveksling og best practice. Viden og erfaringer fra Kvalitetspatruljen har dannet udgangspunkt for både konferencer og publikationer siden, ligesom projektet har skabt en stærkere samarbejdskultur erhvervsskolerne imellem og mellem skolerne og ministeriet.

\section{Kvalitetsudmærkelse i Finland}

Det finske Undervisnings- og Kulturministerium har siden 2000 uddelt en årlig pris til en erhvervsskole, som har udmærket sig gennem nye projekter eller stærke resultater. Prisen har været med til at give erhvervsskolerne et bedre ry i offentligheden. Vinderen findes i samarbejde mellem ministeriet, studerende og finske arbejdsgiverorganisationer.

Kilde: Rekrytering, genomströmning och relevans - en studie av yrkes- och lärlingsutbildningssystemen i Norden, Faugert \& Co., 2014. Rapporten er udarbejdet under "Holdbar Nordisk Velfærd". Find den i projektgalleriet på side 62. 
“I starten af projektet var der mange af deltagerne, der efterlyste beskrivelser af de nordiske erhvervsuddannelser. De ville fx gerne vide, hvordan praktikken er organiseret i de forskellige lande for at føle sig klædt på til at tale med hinanden i netværket. Det kæmpede jeg faktisk lidt imod. Ikke fordi kortlægninger er ligegyldige, men fordi de nogle gange misser nuancerne. Viden er vigtig på vejen mod flere faglærte og bedre erhvervsuddannelser - men det er ikke nok. Vi har også brug for møder mellem mennesker, der forpligter os og tvinger os ud i nye erkendelser. Det er det, vi skal bruge netværket til," fortæller hun.

For Helen Gray har mødet med kollegaer fra andre organisationer, som arbejder med erhvervsuddannelsernes attraktivitet, også ført til et nyt samarbejde med skoler i både Åland, Sverige og Danmark. Sammen vil de gøre det muligt for studerende at tage en del af deres uddannelse $i$ et andet nordisk land og forhåbentlig gøre uddannelserne mere attraktive i fremtiden.

\section{En bred invitation}

For at sikre forskellige perspektiver mellem deltagerne i samtalerne har det været vigtigt for Margaretha Allen, at det nordiske netværk var bredt sammensat, sådan at der både var deltagere fra nationalt og lokalt niveau og fra forskellige sektorer. Deltagerne tæller derfor både de kommunale skoleforvaltninger, arbejdsgivere, skoleledere og embedsmænd på ministerielt niveau.

At den brede invitation er vigtig, bekræfter Magnus Magnussen. Han har sin egen elektrikervirksomhed, er formand for Færøernes Håndværksmesterforening og savner ofte en invitation, når arbejdsløshed, praktikpladser og kvalitet i uddannelserne sættes på dagsordenen.
Derfor var han også hurtig til at takke ja til en plads i netværket, da chancen bød sig:

“Det er mig, der har lærlingene gående hver dag, og mig, der skal sikre, at de her unge mennesker får mest muligt ud af deres praktik og tid på arbejdspladsen. Jeg tror, jeg taler for alle arbejdsgivere på Færøerne, når jeg siger, at vi gerne vil løfte vores del af opgaven," siger han.

Netværket har blandt andet givet Magnus Magnussen mulighed for at tale med nogle af de danske embedsmænd, som laver reglerne for, hvordan virksomheder som hans egen kan oprette praktikpladser. Det gav anledning til en snak om, hvordan de mange regler og rapporteringskrav nogle gange spænder ben for det lokale initiativ. Opfordringen til private virksomheder er ofte, at de skal etablere flere praktikpladser, men Magnus Magnussens erfaring
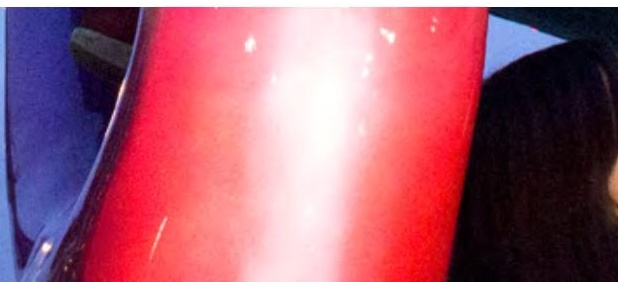


\section{Alt for ofte foregår det nordiske samarbejde på et nationalt myndighedsniveau. \\ 99}

er, at mange bliver skræmt væk, når de opdager den mængde papirarbejde, det kræver at få de unge mennesker inden for på arbejdspladserne.

“Da jeg nævnte det for ministeriets folk, blev de oprigtigt forbløffede. Sådan havde de ikke tænkt på det. De så i stedet de mange regler som en håndsrækning," forklarer Magnus Magnussen om perspektiverne i den brede samtale.

For Margaretha Allen er det netop den slags nuancer, som bredden $\mathrm{i}$ deltagerkredsen sikrer. Nuancer, som er vigtige, når vi skal til bunds i, hvad der er op og ned, og i hvordan vi kan gøre tingene bedre.

"Alt for ofte foregår det nordiske samarbejde på et nationalt myndighedsniveau. Her taler embedsmænd, der arbejder i ministerier og departementer med andre embedsmænd. Det er alt for snævert kun at se på nordisk samarbejde på den måde. Når det handler om at give flere unge fodfæste på arbejdsmarkedet, giver det sig selv, at vi skal have både uddannelsesinstitutioner og arbejdsgivere med ombord. Nogle gange, fordi deres perspektiv er afgørende for at forstå, hvorfor vi ikke lykkes. Og andre gange, fordi de kan gå ud og gøre tingene anderledes allerede i morgen," fortæller hun.

\section{Vi skal skynde os langsomt}

For at få noget ud af samarbejdet i netværket har deltagerne skullet kende hinanden godt. Det er både Helen Gray, Magnus Magnussen og Margaretha Allens erfaring. Eksempelvis var udvekslingen af studerende landene imellem aldrig kommet $\mathrm{i}$ stand uden tiden til at lære de andre deltagere at kende, erkender Helen Gray, udviklingsdirektør i Center for Livslang Læring på erhvervsuddannelsescenteret IDAN i Island:
"Hvis mine elever skal rejse til andre skoler i Norden, er tillid en helt afgørende forudsætning. Jeg skal være sikker på, at de lærer noget, og at der bliver taget hånd om dem. Den tillid har vi fået etableret deltagerne imellem, fordi har vi mødtes så mange gange efterhånden og lært hinanden at kende," fortæller hun.

Derfor er den vigtigste forudsætning for erfaringsudvekslingen og de nye samarbejder da også tid, fortæller Margaretha Allen.

"Det er ikke svært at lade sig inspirere af andre, men det tager tid at nå derhen, hvor samtalerne får værdi og rent faktisk inspirerer. Min største opfordring til andre, der vil skabe læring på tværs af de nordiske lande, er at tage samtalen alvorligt. Den gode samtale skal have tid og rum til at udfolde sig. Det handler om, at vi skal skynde os langsomt," fortæller Margaretha Allen.

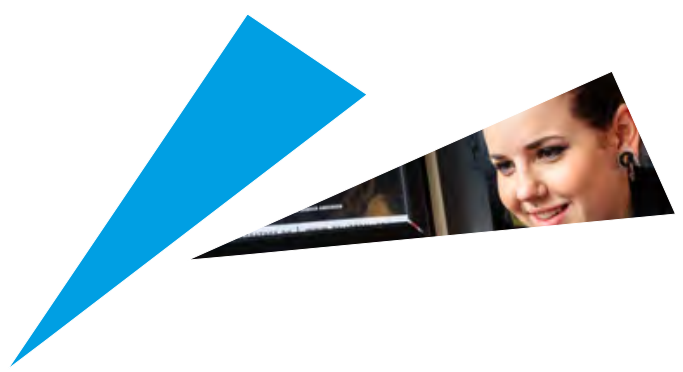




\title{
Innovation på nordisk
}

\author{
Programmet "Holdbar Nordisk Velfærd" har fokus på at finde nye velfærdsløsninger til \\ gavn for Nordens borgere. Og netop innovationskraften er stærk i de nordiske lande, \\ viser internationale undersøgelser. Senest placerer Global Innovation Index fra 2015 \\ alle de fem nordiske lande i top-20 globalt. Men hvad er det, der gør os gode til at \\ tænke nyt i de nordiske lande, og hvordan bliver vi verdensmestre? Vi har bedt to eks- \\ perter om hjælp til at tage temperaturen på den nordiske innovationskraft.
}

\section{HVEM?}

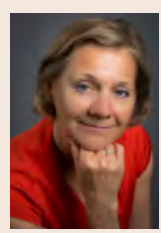

Liisa Välikangas (LV) Professor i Innovation Management, Aalto University \& Hanken School of Economics, Finland

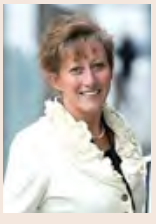

Gillian WarnerSøderholm (GWS) Associate professor og institutleder, Institut for Kultur og Kommunikation, BI Handelshøyskolen, Norge

\section{Hvad betyder "innovation" egentlig?}

LV: Mange tænker, at innovation handler om et slutprodukt, men i virkeligheden skal vi se mere på det som en rodet og forvirrende proces. Jeg plejer at sige, at innovation er en distrahering, lige indtil det øjeblik, hvor processen viser sin værdi og giver gevinst. På den måde handler innovation om at eksperimentere. Den vigtigste ingrediens i den forbindelse er modet til at udfordre kendte vaner og rutiner.

Hvordan er de nordiske landes forudsætninger for det?

GWS: Ser vi på virksomheder og organisationer, så taler forskere om en særlig nordisk ledelsesform, hvor lederen er mere en coach end en chef. Flade magtstrukturer bidrager til idéudvikling, fordi medarbejderne involveres i beslutningerne, og fordi der både fysisk og i overført betydning er kortere vej til chefens kontor, hvis man har en god idé. Derfor er der plads til en anden spontanitet i nordiske organisationer sammenlignet med fx i Asien, hvor fokus er anderledes rettet mod autoriteter og mod at finde sin plads i hierarkiet. Det, at vi i Norden er meget direkte og siger tingene ligeud, er en afgørende forudsætning for innovation, og her adskiller vi os fra resten af verden.

LV: Og så er den helt afgørende og fælles forudsætning for innovation i Norden vores velfærdssamfund. Den udbredte tillid, 
den minimale korruption, den frie og lige adgang til sundhed og det omfattende sociale sikkerhedsnet $i$ form af pensioner og arbejdsmarkedsydelser bidrager til at skabe én ting: tryghed. Det gør det lettere at turde at afprøve alternative løsninger og udvikle nyt, fordi vi har et sikkerhedsnet i ryggen, der griber os, hvis vi fejler.

\section{Så den nordiske model rimer i virkeligheden på innovation?}

GWS: Både og. Velfærdssamfundet er på et overordnet niveau rigtig godt for innovationskraften. Det sikkerhedsnet, som nordiske borgere har, gør, at de relativt omkostningsfrit kan gå videre med idéer og kaste sig ud i nye ting. Omvendt vil jeg vove at påstå, at det nordiske hold ville tabe uendelig stort til lande som Kina og Indien, hvis vi forestiller os de Olympiske Lege i innovation. Simpelthen fordi vi ikke er sultne nok. Vi har det ganske enkelt så godt, at vi risikerer at blive magelige. Så på den måde kan vores velfærdssamfund også fostre en passivitet, hvis vi ikke passer på.

Jeg plejer at sige, at den nordiske viking er blevet blød. Vi har mistet vores killer instinct i Norden. Sat på spidsen har vi måske betalt for vores høje levestandarder med vores konkurrencegen og vores krigeriskhed. Spørger man børn og forældre i de norske folkeskoler, om de er glade og tilfredse, så svarer de ja. Men ser vi på de internationale PISA-undersøgelser, så bliver vi overhalet af resten af verden. Man kan ikke lade være med at tænke, at der er en fare for, at vi bliver tilfredse med middelmådigheden og lidt for glade for det velkendte og komfortable.
LV: Det er et faktum, at den offentlige sektor i Norden er langt mere konservativ end mange af de borgere, den er til for. I disse år ser vi et hav af forskellige bevægelser i de nordiske samfund, hvor borgerne handler sammen på måder, som udfordrer den måde, vi har indrettet velfærdssamfundet på. Måske engagerer de sig i bytteøkonomi, eller måske leverer de selv nogle af de servicer til medborgere, som staten tidligere leverede. Det skal den offentlige sektor - og den nordiske model - indrette sig efter. Et oplagt spørgsmål i den forbindelse er fx, om det er staten og kommunerne, der alene skal sikre borgernes velfærd, eller om vi skal udvikle den nordiske model ved at satse på løsninger, der inddrager og involverer borgerne mere i ligningen?

Betyder det, at der er en særlig nordisk opskrift på innovation?

GWS: Det mener jeg godt, at man kan sige. Når alt kommer til alt, så er vi jo meget forskellige lande med forskellige kulturelle træk. Vi har hver vores forcer. Norges styrke er deres fokus på ligestilling mellem kønnene. Svenskerne er fokuserede på den menneskelige relation og på, at alle er blevet hørt. Danskere er gode til at få tingene gjort og til at optimere processer og arbejdsgange. Og finnerne er gode til struktur og til at forankre beslutningskraften hierarkisk. Det er selvfølgelig stærkt generaliseret, men det peger alligevel på, hvordan et nordisk samarbejde om eksempelvis nytænkning af velfærden bliver stærkere, hvis vi samler kræfterne. Kort sagt så er det samarbejdet, der er opskriften.

LV: I bund og grund kan man finde potentialet for innovation overalt - $\mathrm{i}$ alle mennesker og $\mathrm{i}$ alle 


\section{$\frac{\frac{D}{2}}{\text { D. }}$}

$-x^{2}$

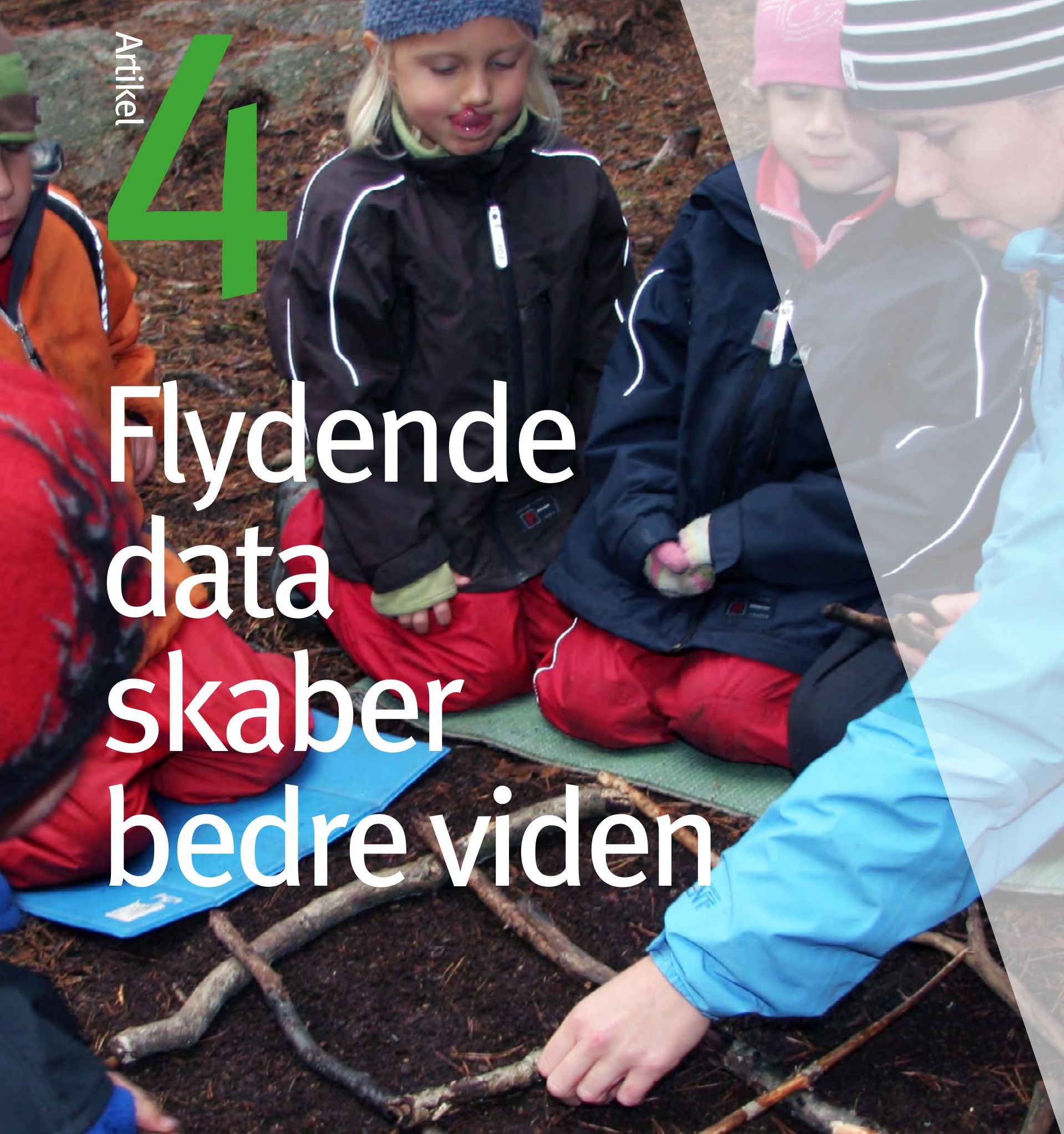


Mennesker, som bliver ramt af kræft, mens de er børn, er mere syge i voksenlivet end andre. Det er de, fordi kræftsygdommen og især behandlingen øger risikoen for senfølger i børnenes voksenliv, simpelthen fordi kroppens organer bliver mere sårbare over for en række forskellige sygdomme. Ud over de helbredsmæssige konsekvenser af en kræftsygdom i barndommen ved forskerne imidlertid kun lidt om, hvilken betydning kræft i de tidlige år har for, hvordan børnenes liv i øvrigt udvikler sig.

Det vil Jeanette Falck Winther, overlæge og seniorforsker hos Kræftens Bekæmpelse i Danmark, undersøge for at finde ud af, om børn, der får kræft i barndommen, udover mere sygdom, generelt klarer sig dårligere i voksenlivet end andre børn.

"Vi ved ikke nok om, hvordan det at overleve en alvorlig sygdom som kræft påvirker børnene senere i livet. Hvilke uddannelser tager de, stifter de familie, og får de fodfæste på arbejdsmarkedet?" forklarer hun.

For at komme svarene nærmere har hun og et team af forskere sat sig for at etablere en ny og udvidet fælles nordisk database. Den skal kombinere allerede indsamlet data om de kræftramte børns helbred og sygdomsforløb med data om deres liv i øvrigt, fx hvilken uddannelse de tager, og om de stifter familie.

Den udvidede, fælles database er et eksempel på det potentiale, der er i at dele data på tværs af Norden, simpelthen fordi antallet af data mangedobles, når man arbejder med hele Norden i stedet for med landene hver for sig, forklarer Maria Nilsson. Hun er seniorrådgiver hos NordForsk (en nordisk rådgivnings- og finansieringsorganisation for forskning, red.) og ansvarlig for et treårigt projekt under "Holdbar Nordisk Velfærd", som skal gøre det lettere for forskere som Jeanette Falck Winther at få adgang til data på tværs af Norden.

“Når vi skal finde sammenhænge mellem borgeres sundhed og liv i $\emptyset$ vrigt, gør det en kæmpestor forskel, at vi kan se på 26 mio. i stedet for 5 mio. borgere. Det betyder, at vi kan blive klogere på, hvad der bestemmer, hvordan vores liv udvikler sig: hvilken uddannelse vi tager, hvilke sygdomme vi udvikler, hvor mange penge vi tjener osv. I sidste ende kan datadeling på tværs af grænserne forbedre livskvaliteten for borgere i hele Norden," forklarer Maria Nilsson.

Jeanette Falck Winther er enig. Hun håber på, at de nordiske velfærdssamfund på baggrund af den nye viden, som det nordiske forskningsprojekt skaber, kan hjælpe de kræftramte børn bedre på vej i livet,

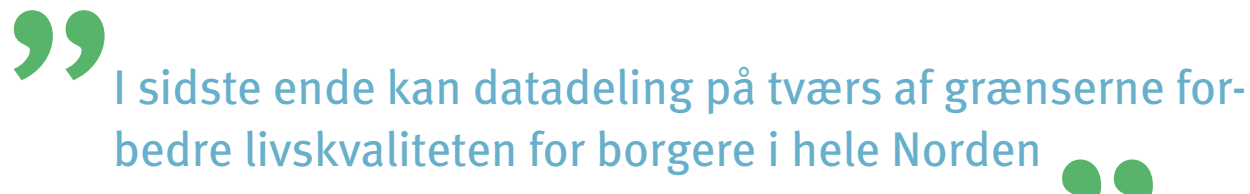




\section{-}

eksempelvis med støtte og vejledning, så deres forudsætninger bliver mere lig andre børns.

Find andre eksempler på, hvordan forskning under "Holdbar Nordisk Velfærd" sætter ulighed i sundhed og velfærd på dagsordenen ved hjælp af tværgående data i boks 10 . Og bliv klogere på, hvordan tværgående nordiske studier baner vej for nye og bedre lægemidler i boks 13 .

\section{Solidt grundlag}

Heldigvis er de nordiske lande godt stillet i forhold til at høste gevinsterne ved at dele data, fordi de har ekstraordinært gode databanker om deres borgere, forklarer Erland Hjelmquist, der er professor emeritus i psykologi på Göteborg Universitet i Sverige og tidligere generalsekretær i det svenske forskningsråd Forte (forskningsrådet for sundhed, arbejdsliv og velfærd, red.).

“De nordiske lande deler en århundredelang lang tradition for at registrere og gemme oplysninger om hver enkelt borger. Helt tilbage til det 17. århundrede har vi informationer om, hvor folk boede, hvem de giftede sig med, og hvilken uddannelse de tog," fortæller han.

Mens det oprindeligt var den lutherske kirke, der stod for at indsamle data om deres borgere, er det i dag en integreret del i de nordiske velfærdssamfund, som har store databanker og registre. De indeholder både sundhedsdata om lægebesøg, medicinforbrug og hospitalsindlæggelser og såkaldt sociale data om borgernes uddannelse og beskæftigelse.

“Når vi kombinerer det med, at alle nordiske borgere har et personnummer, står vi med helt unikke muligheder for at studere alle mulige sammenhænge på tværs af Norden, fx udviklingen i folkesundhed over tid eller sammenhængen mellem uddannelse og helbred," forklarer Erland Hjelmquist.
Han peger på, at det afgjort er et særligt nordisk fællestræk, at man fra centralt hold har interesseret sig for at følge borgeres gøren og laden gennem så lang tid. Andre europæiske lande som Italien og Tyskland har ikke den samme tradition for individspecifikke oplysninger og har heller ikke arbejdet med det så længe, som vi har i Norden, forklarer han.

\section{Bump på vejen}

Selvom potentialerne er store, og datagrundlaget er på plads, så er det at dele data på tværs af de nordiske grænser endnu ikke problemfrit. Det vidner et meget begrænset antal fælles nordiske registre og databaser om.

Bo Könberg, tidligere sundhedsminister i Sverige, beskriver nogle af de barrierer, som hindrer datadelingen i rapporten Det framtida nordiska hälsosamarbetet. Rapporten er udarbejdet under "Holdbar Nordisk Velfærd" og handler om, hvordan man kan styrke og udvikle det nordiske samarbejde på sundheds- 


\section{BOKS 10}

\section{Ulighed i Norden - vi skal vide mere om ...}

Hvorfor unge flygtninge i de nordiske velfærdssamfund klarer sig dårligere i livet Unge flygtninge klarer sig dårligere socialt, $ø$ konomisk og sundhedsmæssigt end deres medborgere. Projektet "Coming of Age in Exile" er et samarbejde mellem ledende forskningsgrupper i de nordiske lande, som vil undersøge årsagerne til uligheden, bl.a. ved hjælp af fælles registre og interviews.

\section{Hvordan arbejdsmarkedet kan rumme flere} Forskning viser, at mennesker med fleksible arbejdstider er sundere og går senere på pension. Projektet "Working hours, health, well-being and participation in working life" undersøger, hvordan fleksible indretninger af arbejdstiden i Norden kan hjælpe flere ind på arbejdsmarkedet. Det handler eksempelvis om, hvordan fleksible arbejdstider kan fastholde ældre på arbejdsmarkedet længere og hjælpe flere handicappede borgere i job.

\section{Hvordan luftforurening påvirker folke- sundheden}

Flere og flere dødsfald er relateret til luftforurening. Forskningsprojektet "NordicWelfAir" skal kortlægge luftforureningens konsekvenser for at blive klogere på, hvem der oftest bliver ramt. Projektet undersøger også luftforureningsniveauer i alle de nordiske lande for at estimere, hvilke konsekvenser luftforurening kan have for folkesundheden i Norden på lang sigt.
Hvordan stress kan forebygges bedre Arbejdspladsen har afgørende betydning for menneskers sundhed - både fysisk og psykisk. Desværre slider arbejdslivet også for mange op. Projektet "Psychosocial work environment and healthy ageing" bygger på observationsstudier i alle de nordiske lande, som har til formål at skabe ny viden om, hvordan arbejdsmiljøet bedst muligt kan understøtte medarbejdernes sundhed og trivsel.

\section{Hvorfor nogle bliver ældre end andre} Forskere ved endnu meget lidt om, hvad der har betydning for, hvordan Nordens borgere ældes, og hvor syge de bliver undervejs. Projektet "Social Inequalities in Ageing" ser nærmere på, hvad der har betydning for at opnå en høj alder og et godt helbred. Projektet undersøger også, hvordan ældreplejen kan indrettes på måder, der understøtter sund aldring.

De fem forskningsprojekter er delvist finansieret af projektet "Forskning i social ulighed inden for sundhed og velfærd", som har været en del af "Holdbar Nordisk Velfærd". Find det i projektgalleriet på side 62. Projekterne er desuden en del af NordForsks program "Nordic Programme on Health and Welfare". 


\section{Boks 11}

\section{Læs mere om anbefalingerne til fremtidens nordiske sundheds-samarbejde}

Det framtida nordiska hälsosamarbetet

området i fremtiden. Bo Könberg påpeger først og fremmest, at flere aktører, eksempelvis de nordiske statistikbureauer og sundhedsregistre, er nødt til at finde fælles fodslag på området og forenkle reglerne for at udveksle data mellem landene, hvis vi skal i mål. Find rapporten $\mathrm{i}$ boks 11 .

\section{Maria Nilsson fra NordForsk peger også på, at en af de største forhin- dringer for udvekslingen af data sta- dig er af praktisk karakter, simpelt- hen fordi det er enormt tidskrævende for forskere at få adgang til dataene i de nordiske lande.}

“I dag skal forskere manuelt søge om adgang til data i hvert enkelt land og afvente de enkelte institutioners godkendelse. I praksis betyder det, at vigtig viden går tabt, fordi det kan tage flere år at få adgang til relevant data. Det kan et forskningshold tit ikke vente på, og derfor bliver løsningen at holde sig til nationale data," fortæller hun.

\section{Hurtig proces}

For at gøre det nemmere og hurtigere for forskere at få adgang til data i de forskellige lande har et nyt samarbejde mellem alle de nordiske statistikbureauer set dagens lys. Det er NordForsk, der har opfordret statistikbureauerne til at finde fælles fodslag, og resultaterne er gode, fortæller Claus-Göran Hjelm, som er afdelingsdirektør i Statistiska centralbyrån i Sverige og leder samarbejdet mellem statistikbureauerne.

\section{"Vi arbejder blandt andet sammen} om at samtænke dele af vores systemer for at lette ansøgningsarbejdet for forskerne og speede processen op, fx ved at lave fælles procedurer for, hvordan forskere skal søge om at få adgang til data," siger han.

På sigt er ambitionen, at forskerne kun skal udfylde én type skema, når de ønsker adgang til data, i stedet for ét nyt skema for hvert land. Eksempelvis arbejder Jeanette Falck Winther, overlæge og seniorforsker hos Kræftens Bekæmpelse i Danmark, sammen med statistikbureauerne om at udvikle skemaet og forenkle ansøgningsprocessen i forbindelse med hendes projekt om kræftramte børn.

Selv ser Jeanette Falck Winther frem til den forenklede proces. Hun har tidligere arbejdet med at samle store datasæt med data fra flere af de nordiske lande, og ligesom Maria Nilsson er hendes erfaring, at det er en tidskrævende proces.

“På sigt håber jeg selvfølgelig på, at jeg som forsker kan få hurtigere adgang til data, fordi det vil betyde, at jeg kan komme i gang med det forskningsmæssige arbejde tidligere i projektperioden. Det fælles ansøgningsskema er et fint signal om, at vi er på vej mod fælles nordisk fodslag på området," fortæller Jeanette Falck Winther.

Dan dig et overblik over de nordiske dataejere i boks 12 .
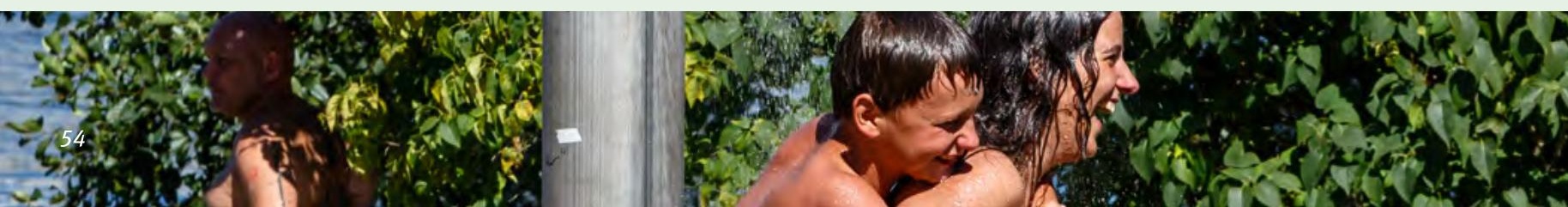


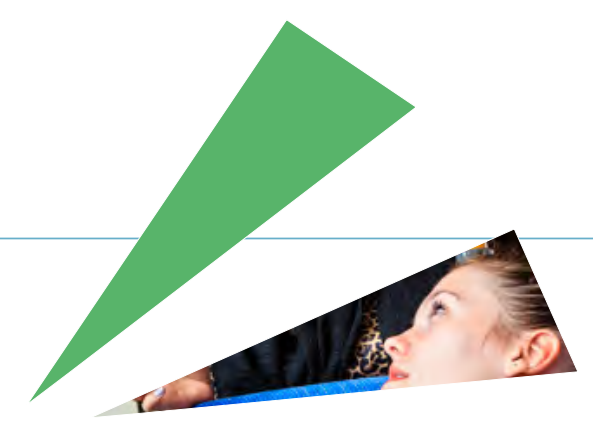

\section{Sund skepsis}

At hvert enkelt af de nordiske lande endnu passer godt på sine data, forstår Erland Hjelmquist, professor emeritus i psykologi på Göteborg Universitet i Sverige, imidlertid godt.

"De nationale datasystemer er kun opstået, fordi der har været en stor tillid til autoriteterne i hvert land. Borgerne stoler på, at deres oplysninger bliver behandlet fortroligt, og de nationale registre nyder stor integritet i hvert land. Derfor værner dataejerne forståeligt om deres procedurer, eksempelvis hvad angår den etiske godkendelse af de projekter, som vil bruge deres data," forklarer Erland Hjelmquist:

"I sidste ende er det jo borgernes tillid til systemerne, der er på spil."

Derfor er han også enig med Bo Könberg i, at centrale aktører som fx statistikbureauerne skal blive enige om fælles procedurer for udveksling af data, som giver alle parter - myndigheder, statistikbureauer og borgere - vished for, at oplysningerne er sikre. Eksempelvis gennem fælles retningslinjer for, hvordan data anonymiseres.

"Hvis vi skal have etableret flere nordiske registre, så skal vi garantere borgernes sikkerhed, når vi udveksler data om dem, eksempelvis ved at blive enige om de samme retningslinjer for, hvordan vi anonymiserer data. Kun sådan kan vi på sigt gøre det nemmere for forskere at få adgang til data på tværs af Norden."

De fælles nordiske retningslinjer for brugen af data står også højt på ønskesedlen hos Jeanette Falck Winther. Dem er hun nemlig fuldstændig enig i, at der er brug for.

“Det er naturligvis acceptabelt og på sin plads, at statistikbureauerne vægrer sig ved at frigive data til mig som forsker, hvis jeg ikke er underlagt nogle regler, som sikrer, at de data, jeg får adgang til, bruges med stor omtanke og til et formål, der bidrager med væsentlig ny viden," fortæller hun.
Boks 12

\section{Hvem har dataene?}

Danmark: Statens Serum Institut (SSI) og Danmarks Statistik. Norge: Folkehelseinstituttet og Statistisk sentralbyrå.

Sverige: Socialstyrelsen og Statistiska centralbyrån.

Finland: Institutet för hälsa och välfärd og Statistics Finland.

Island: The Directorate of Health og Statistics Iceland.

Kilde: Joint Nordic Registers and Biobanks - A goldmine for health and welfare research, NordForsk, 2014. 


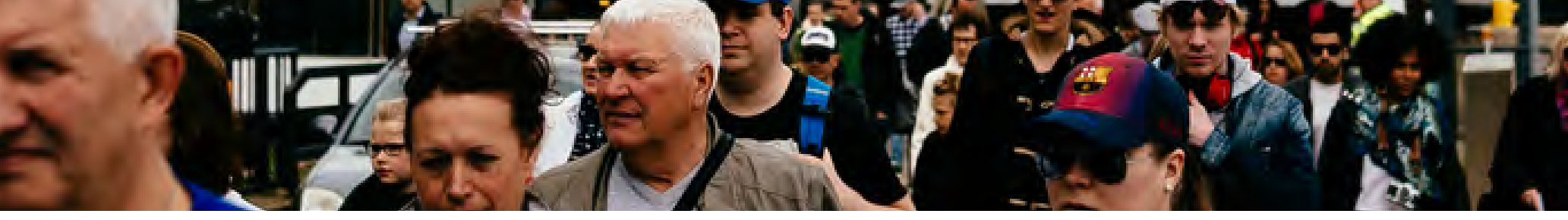

\section{Sikker proces}

For Claus-Göran Hjelm, som leder samarbejdet mellem statistikbureauerne, er det særligt tilliden statistikbureauerne imellem, som det nyetablerede samarbejde har hjulpet på vej. Og tillid er første skridt mod de fælles retningslinjer for behandlingen af data, som Erland Hjelmquist og Jeanette Falck Winther efterlyser.

“Det at mødes med hinanden giver en anden anledning til at lufte nogle af de bekymringer, som dataejerne i de enkelte lande har i forbindelse med datadelingen. Borgernes sikkerhed har altid været udgangspunkt for vores diskussioner, men ved at sidde rundt om samme bord har vi kunnet tage skridtet videre og også nærme os nogle retningslinjer, som alle parter stoler på,” siger han og understreger, at de enkelte statistikbureauer selvfølgelig stadig er underlagt national lovgivning på området.

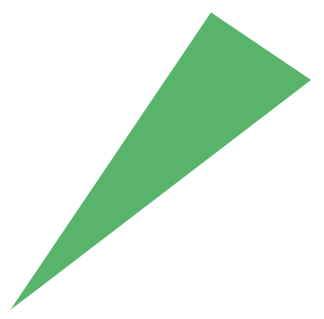

Indtil videre arbejder statistikbureauerne på en fælles sikkerhedsaftale om, hvilke regler for anvendelsen af data der gælder for de forskere, som får dem udleveret. En sådan aftale vil betyde, at både forskere og statistikbureauer fremover skriver under på samme aftale, ligegyldigt hvilket land dataene kommer fra, og altså slipper for at være underlagt forskellige retningslinjer i hvert land.

Samtidig etablerer statistikbureauerne i de kommende år et nordisk metadatabibliotek, som skal give forskere i Norden én fælles indgang til alle de data, som findes i de nordiske lande. Her kan de hurtigt danne sig et overblik over, hvilke data der findes i Norden, og hvilke registre de findes i. Biblioteket skal også strømline dataene, så forskerne kan være sikre på, at de er sammenlignelige.

Og så længe sikkerheden er på plads, giver det rigtig god mening at hjælpe forskerne til lettere at kunne danne sig et overblik over den data, der findes, mener Erland Hjelmquist. Selvom de nationale statistikbureauer på tværs af Norden har indsamlet data i mange år, er der nemlig forskel på, hvordan dataene er kategoriseret. Det gør det svært at sammenligne data, når vigtige variable er defineret forskelligt, fortæller Erland Hjelmquist og påpeger, at eksempelvis "arbejdsløshed" er et begreb, som optræder forskelligt i de nordiske databanker.

“Det kan ærligt talt være lidt en af en jungle af finde rundt i de enorme mængder data, som findes," siger han.

\section{Ud af starthullerne}

Selvom der endnu er bump på vejen, oplever både Erland Hjelmquist, Claus-Göran Hjelm, Jeanette Falck Winther og Maria Nilsson hver især stor velvilje over for samarbejdet om dataudvekslingen, både fra de nationale statistikbureauer, forskningsmiljøerne og fra nationale beslutningstagere: 


\section{Boks 13}

\section{6. mio. borgere er bedre end 5 mio.}

“Udgangspunktet for samarbejdet kunne ikke være bedre, for alle de involverede aktører er enige om, at der er et uudnyttet potentiale. $\mathrm{Og}$ vi ved, at de barrierer, der er, kan overvindes. Det væsentlige er, at vi sammen bliver enige om hvordan, så vi lander på nogle procedurer, som alle er trygge ved, og som kan holde i fremtiden," siger Maria Nilsson fra NordForsk.

Erland Hjelmquist er fortrøstningsfuld, men vurderer også, at det er nu, de nordiske lande skal rykke, hvis de skal bevare det nordiske momentum inden for forskning i velfærd og sundhed:

"Selvom vi er gode, kan vi altid blive bedre. Hvis vi holder op med at forbedre os, så bliver vi lynhurtigt indhentet af omverdenen, og så må vi jo indse, at vi ikke længere er helt så langt, som vi troede. Det skal vi for alt i verden undgå, for vi har guldgruben til forskning i verdensklasse lige for næsen af os."
Udover fælles registre og databanker er Nordens mange mennesker også værdifulde, når forskere og lægemiddelindustrien skal udvikle bedre behandlinger og lægemidler. Det gælder fx, når det handler om kliniske studier, hvor man tester, hvordan nye typer behandlinger eller medicin virker på patienterne.

Desværre er antallet af kliniske studier i Norden faldet drastisk i løbet af de sidste 30 år. Spørger man Pierre Lafolie, der er overlæge på Karolinska Universitetssjukhuset i Sverige, skyldes nedgangen blandt andet, at de nordiske lande hver for sig ikke er særligt attraktive for forskere eller medicinalvirksomheder. De er nemlig for små:

“Især når vi skal teste behandlinger af sjældne sygdomme, er det vigtigt, at de kliniske studier har et stort befolkningsgrundlag at rekruttere patienter fra. Hvis befolkningsgrundlaget er for lille, i forhold til hvor sjælden sygdommen er i befolkningen, så rykker de kliniske studier til lande, hvor der bor flere mennesker," forklarer han.

Udover på sigt at kunne tilbyde patienterne de nyeste lægemidler hurtigere vil flere fælles nordiske studier også betyde, at man ikke behøver gentage studierne i hvert land, sådan som det ellers er tilfældet i dag. Derfor har NordForsk etableret et nordisk samarbejde, som skal kickstarte flere kliniske studier på tværs af Norden, "Nordic Trial Alliance". Pierre Lafolie er tilknyttet samarbejdet som ekstern projektleder.

"Nordic Trial Alliance" samler forskere, hospitaler, medicinalvirksomheder og patientforeninger, som arbejder sammen mod at forløse Nordens potentiale for fælles kliniske studier. Udover at facilitere kontakten mellem medicinalvirksomheder og hospitaler har netværket også lanceret en hjemmeside, hvor patienter i Norden kan få et overblik over, hvilke studier der er relevante for dem. I 2015 søsatte alliancen i samarbejde med NordForsk sine første fælles kliniske studier.

Projektet "Nordisk samarbejde om kliniske studier" er en del af "Holdbar Nordisk Velfærd". Find det i projektgalleriet på side 62. 


\section{Arbejdet fortsætter}

Selvom programmet "Holdbar Nordisk Velfærd" er slut, fortsætter det nordiske samarbejde om velfærden. Derfor er det oplagt at lade afslutningen af programmet være anledning til refleksion. $0 g$ til at dele erfaringer om det at samarbejde, så nye samarbejder kan blive så robuste og effektive som muligt.
Den 26.-27. november 2015 afholdt Nordisk Ministerråd afslutningskonference for programmet "Holdbar Nordisk Velfærd". Konferencen samlede en række af de mange mennesker, der i løbet af programmets tre år har været en del af de i alt 17 samarbejdsprojekter, der til sammen udgør "Holdbar Nordisk Velfærd".
På konferencen spurgte vi deltagerne, hvad de har lært om at samarbejde gennem de sidste tre år, og hvilken læring de tager med sig ind i fremtidige samarbejder. Hvad gik godt? Hvad skal vi gøre mere af? Og hvad skal vi lade være med i fremtiden?

Se deres bud på en checkliste til det gode samarbejde på næste side.

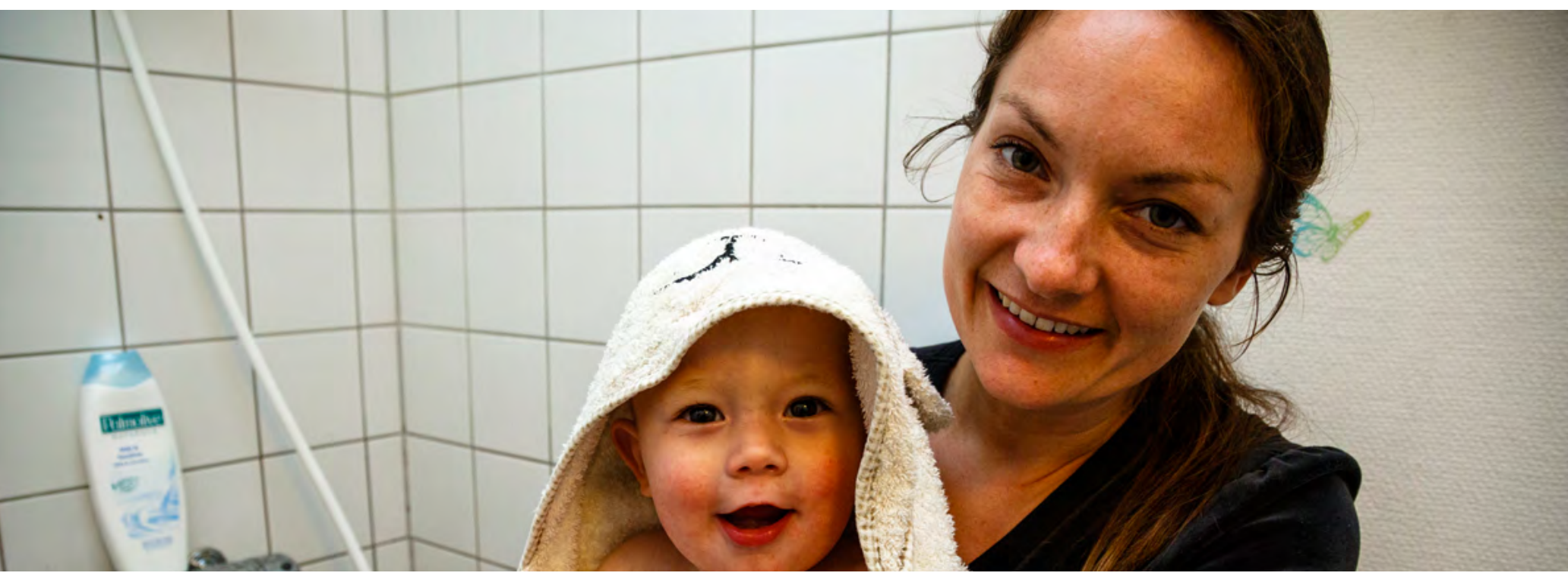




\section{Checkliste til det gode samarbejde}

\section{Invitér bredt}

Inddrag dem, det handler om. Det kan være de borgere, som er målgruppen. Eller det kan være aktører med andre perspektiver på problemstillingen som f.eks. private virksomheder, lokale myndigheder, uddannelsesinstitutioner eller NGO'er.

\section{Spørg hvordan og ikke kun hvorfor}

Hvordan gør man det i praksis, altså samarbejder? Det betyder meget, hvordan et nordisk samarbejde skrues sammen, hvor tit man mødes, hvordan møderne struktureres, og hvor meget tid der er til at lære hinanden at kende. Første skridt mod at gøre en forskel er at blive skarpe på, hvordan man kommer derhen. $0 \mathrm{~g}$ at prioritere den tid, det tager.

\section{Fokusér på forankring}

Gode samarbejder skal forankres organisatorisk for at leve. Hvis et projekt skal skabe reelle resultater, skal der være nogen, der føler ejerskab over det og sørger for at drive det frem - også efter en projektperiode er slut. Det sikrer engagement og gejst, når samarbejdet drives af dem, som virkelig brænder for det.

\section{Kommunikér gevinsterne}

Vær skarp på, hvilken forskel samarbejdet skal gøre og for hvem. Sæt ord på værdien, og prioritér kommunikationen udadtil, så omverdenen - politikere, borgere og organisationer - bliver opmærksom på, hvad vi arbejder sammen om i Norden, og hvad vi har opnået.

\section{Følg op}

Overvej, hvordan samarbejdets resultater kan inspirere fremtidigt arbejde på området - også selvom samarbejdsprojektet er slut. Det handler ikke kun om at dele resultater, men også om at lære af det, som ikke fungerede.

Note: Checklisten er udarbejdet på baggrund af konferencen "Holdbar Nordisk Velfærd - hvordan?" og bygger på deltagernes erfaringer med og råd til det videre samarbejde. Det er Mandag Morgen, der har foretaget tværlæsningen af deltagernes inputs.

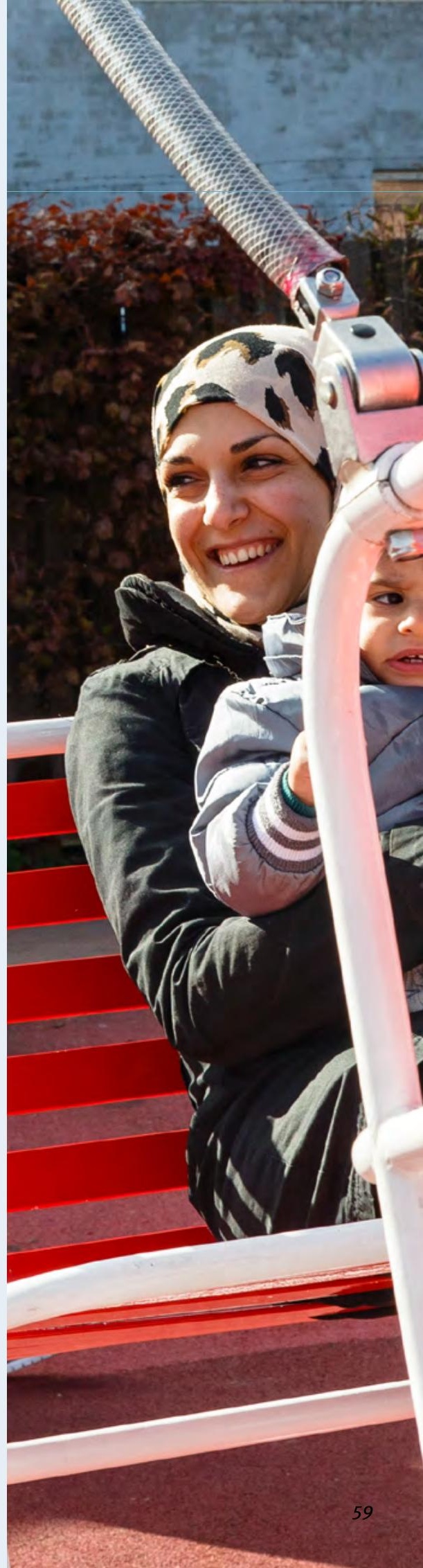




\section{Vejen videre - et nyt program}

Vatten, natur och människor

\begin{abstract}
Arbejdet med at udvikle velfærden i Norden fortsætter under det finske formandskab, som i 2016 har ordførerskabet i Nordisk Ministerråd under overskriften "Vand, natur og mennesker". Se boks 14 .
\end{abstract}

Helt konkret forankres det videre arbejde med at udvikle velfærd i Norden i programmet "Ett öppet och innovativt Norden med välmående människor 2020 - Lika möjligheter till välfärd, utbildning, kultur och arbete", som i 2016-2018 inviterer aktører fra hele Norden til at fortsætte samtalerne om, hvordan vi sikrer bæredygtig velfærd i fremtiden.

Det treårige program bygger på de resultater og erfaringer, der er skabt under "Holdbar Nordisk Velfærd" og fokuserer på at videreudvikle det nordiske samarbejde om velfærd, både inden for uddannelse, arbejde, forskning og - som noget nyt kultur. Udviklingen af samarbejdet kommer særligt til an handle om at dyrke snitflader på tværs af sektorer og om at invitere en række forskellige og nye aktører ind i samtalerne, herunder dem, det hele handler om - borgerne.

Som noget nyt fokuserer programmet på at imødekomme den stigende globale interesse for den nordiske model. Blandt andet etableres et "Team Nordic" bestående af eksperter og politikere fra alle de nordiske lande. Deres opgave bliver at profilere den nordiske velfærdsmodel for et internationalt publikum. Når programmet slutter i 2018 , er ambitionen, at der er etableret et såkaldt nordisk kundskabs- og kompetencecenter, "Nordic Centre of Excellence", som kan bistå både nationale og internationale aktører $i$ arbejdet med velfærdsudvikling.

Ligesom "Holdbar Nordisk Velfærd" fokuserer det nye program på at håndtere nogle af de udfordringer, som de nordiske lande står over for i de kommende år. Ikke med ambitionen om at løse udfordringer som eksempelvis den demografiske udvikling eller en øget global konkurrence én gang for alle. Men fordi vi sammen kan - og skal - blive klogere på, hvordan vi håndterer dem bedst og indretter os smartest efter dem.

Programmet adresserer samtidig nye og mere akutte udfordringer, der kalder på, at de nordiske lande samarbejder. Ligesom resten af verden oplever Norden i disse år historisk store flygtningestrømme, som presser vores velfærdssystemer. Derfor vil det nordiske samarbejde om at udvikle bæredygtig velfærd også handle om flygtninge. Ikke fordi landene skal opnå politisk enighed om, hvordan situationen håndteres i de enkelte lande - eller fordi der nødvendigvis skal findes én nordisk løsning. Men fordi samtalen landene imellem er central på vejen mod nationale løsninger, der virker. Og for at sikre, at den nordiske velfærd også er bæredygtig i fremtiden. 


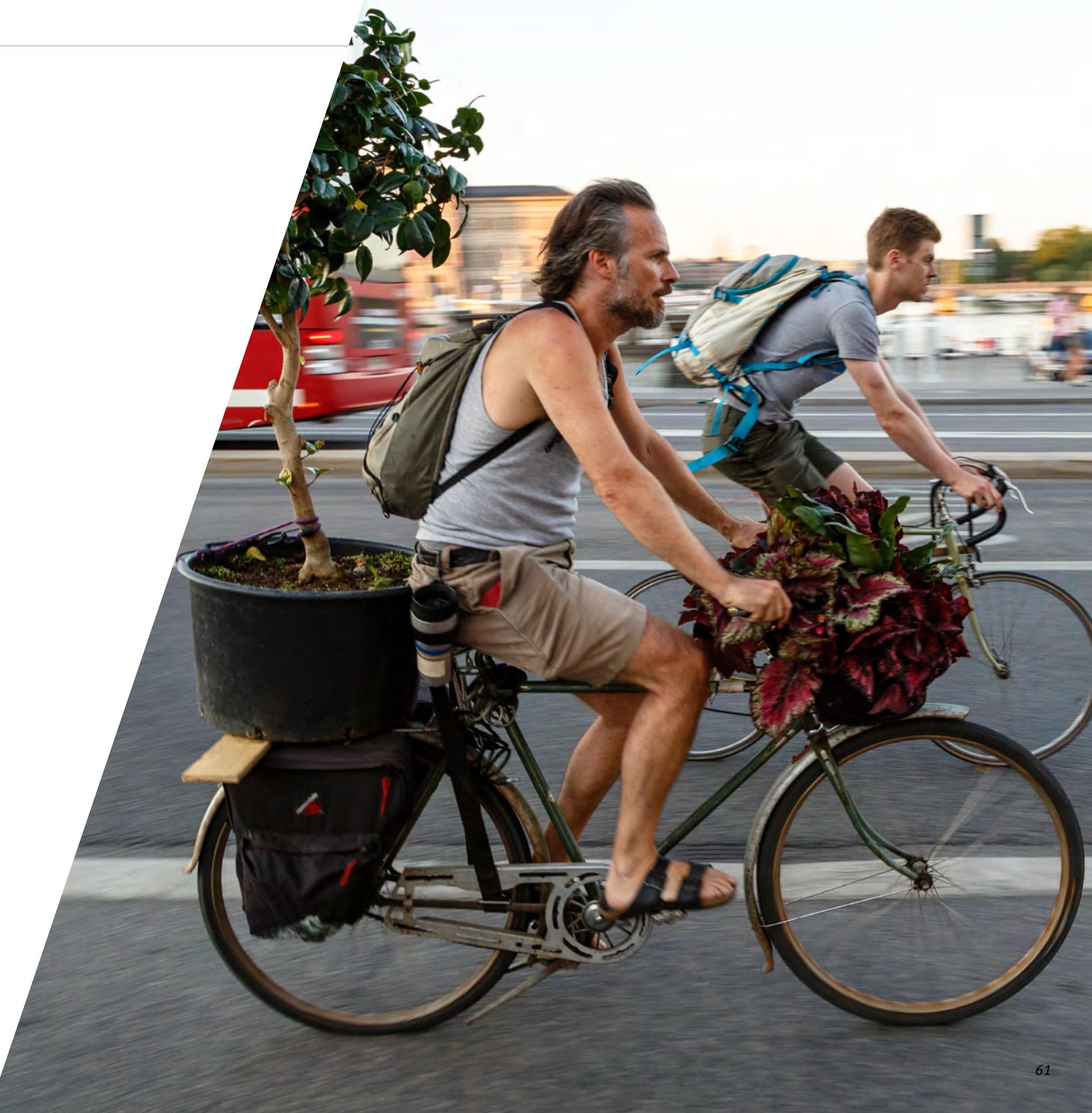




\section{Projektgalleri}

17 projekter er en del af Holdbar Nordisk Velfærd.

Dan dig et overblik på de næste sider.

\section{FORSKNING FOR VELFARD}

\section{Rekruttering og fastholdelse af ansatte i plejesektoren}

Et velfærdssamfund, som kan tilbyde gode omsorgs- og plejeydelser i fremtiden, kræver bedre rekruttering og fastholdelse af personale i plejesektorerne. Projektet har udarbejdet en rapport, som kortlægger udfordringer og muligheder.

Læs mere om projektet her.

Kontakt: Trond Nygaard, seniorrådgiver, Helse- og omsorgsdepartementet, Norge, trond.nygaard@hod.dep.no

\section{Forskning i social ulighed inden for sundhed og velfærd}

Selvom de nordiske lande er blandt de mest lige i verden, er der også stadig markante uligheder, og forskere ved stadig for lidt om, hvorfor nogle mennesker klarer sig dårligere i livet. Projektet medfinansierer fem 5 -årige forskningsprojekter, som skal bidrage med ny viden om, hvordan de nordiske samfund kan mindske ulighederne inden for sundhed og velfærd i fremtiden.

Læs mere om projektet her.

Kontakt: Maria Nilsson, seniorrådgiver, NordForsk, maria.nilsson@nordforsk.org

\section{Den nordiske velfærdsvagt}

Finanskrisen har udfordret de nordiske velfærdssamfund, og der er brug for mere viden om, hvordan forskellige kriser påvirker vores samfund, så de kan stå fremtidige kriser imod. Projektet har bl.a. udviklet indikatorer, som kan anvendes til at identificere nye og kommende velfærdsbehov $\mathrm{i}$ befolkningen, herunder $\mathrm{i}$ forbindelse med krisehåndtering.

Læs mere om projektet her.

Kontakt: Ingi Valur Jóhannsson, politisk rådgiver, Velfærdsministeriet, Island, ingi.v.johannsson@vel.is

\section{Rapport om det fremtidige nordiske sundheds- samarbejde}

Hvordan kan det nordiske sundhedssamarbejde udvikles og styrkes i de kommende år? Bo Könberg, tidligere sundhedsminister i Sverige, kommer i denne rapport omkring udfordringer og potentialer i et styrket nordisk samarbejde og præsenterer 14 konkrete anbefalinger til indsatsområder.

Læs rapporten her.

Kontakt: Astrid Utterström, seniorrådgiver, Nordisk Ministerråd, asut@norden.org

\section{UDDANNELSE OG ARBEJDE TIL VELFARD}

\section{Nordisk vidensbank om frafald i skolen}

For at sikre, at flere unge gennemfører en uddannelse, har dette projekt lanceret en nordisk vidensbank, som samler værktøjer, metoder og gode eksempler på, hvordan uddannelsesinstitutioner kan hjælpe flere unge til at blive i uddannelsessystemet.

Læs mere om projektet her.

Kontakt: Jenny Tägström, projektleder, NordForsk, jenny.tagstrom@nordicwelfare.org 


\section{Studie af erhvervs- og lærlingesystemerne i Norden}

Ungdomsarbejdsløsheden i Norden steg voldsomt efter finanskrisen, og mange unge har endnu svært ved at få fodfæste på arbejdsmarkedet efter endt uddannelse. Dette studie ser nærmere på barrierer i overgangen mellem uddannelse og arbejdsmarked og klarlægger de udfordringer, behov og visioner, som kendetegner Nordens erhvervsuddannelser.

Læs rapporten her.

Kontakt: Johanna Enberg, konsulent, Faugert \& Co., johanna.enberg@faugert.se

\section{Socialt entreprenørskab}

Socialt entreprenørskab handler om at finde nye løsninger på sociale problemer i de nordiske samfund, eksempelvis hvordan flere udsatte mennesker får fodfæste på arbejdsmarkedet. Projektet kortlægger nuværende indsatser i Norden inden for socialt entreprenørskab og kommer med anbefalinger til, hvordan vi booster arbejdet med at inkludere udsatte grupper $\mathrm{i}$ arbejds- og samfundslivet i Norden.

Læs rapporten her.

Kontakt: Aase Lunde, seniorrådgiver, Arbeids- og sosialdepartementet, Norge, Aase-lunde@asd.dep.no

\section{Læring på arbejdspladsen}

Alle de nordiske lande kæmper med frafald på erhvervsuddannelserne og høj ungdomsarbejdsløshed. For at møde de udfordringer og sikre flere dygtige faglærte i fremtidens velfærdssamfund har projektet etableret et nordisk netværk, hvor både lokale og regionale aktører mødes for at lade sig inspirere af hinanden. Det handler bl.a. om, hvordan vi bygger bedre bro mellem uddannelse og arbejdsmarked.

Læs mere om projektet her.

Kontakt: Margaretha Allen, uddannelsesdirektør, Skolverket, Sverige, margaretha.allen@skolverket.se

\section{Entreprenørskab i uddannelserne}

Projektet fokuserer på at styrke lærernes undervisningskompetencer inden for innovation og entreprenørskab, bl.a. ved udarbejdelse af en fælles nordisk kompetenceramme for entreprenørskab i grundskolen. Projektet har også udgivet et katalog med gode eksempler på entreprenørskab i de nordiske grundskoler, som kan inspirere flere til på sigt at tænke entreprenørskab ind i skoleskemaet.

Læs mere om projektet her.

Kontakt: Morten Friis Møller, seniorrådgiver, Nordisk Ministerråd, momo@norden.org

\section{Nordisk master inden for velfærd}

Under Nordisk Ministerråds program Nordic Master, er der fra 2015 øremærket midler til en ny nordisk master med fokus på velfærd. Det er Stavanger Universitet i Norge, som har fået bevillingen til i samarbejde med Aalborg Universitet i Danmark og Umeå Universitet i Sverige at etablere uddannelsen Master in Social Work and Welfare. Første hold studerende starter i efteråret 2017.

Læs mere om projektet her.

Kontakt: Kai Koivumäki, seniorrådgiver, Nordisk Ministerråd, kkoi@norden.org 


\section{Mobilitet og anerkendelse af erhvervs- kvalifikationer i Norden}

Fremtidens pleje- og sundhedssektorer bliver bedre, hvis studerende og fagfolk kan studere og arbejde i alle de nordiske lande. Projektet har kortlagt de nordiske landes krav for godkendelse af erhvervsuddannelser på tværs af landene. På baggrund af projektets resultater er der nedsat en tværministeriel samarbejdsgruppe, som arbejder med at implementere anbefalingerne.

Læs rapporten her.

Kontakt: Morten Friis Møller, seniorrådgiver, Nordisk Ministerråd, momo@norden.org

\section{Velfærdsprofessioner i Norden}

Projektet har blandt andet gennemført et sammenlignende studie af, hvordan der i de nordiske lande arbejdes med at integrere forskning i uddannelserne på velfærdsområdet og klarlagt velfærdsforskning på tværs af Norden for at undersøge, hvordan forskningen er forankret $i$ velfærdsuddannelserne i Norden.

Kontakt: Marianne Aastebøl Minge, seniorrådgiver, NordForsk, marianne.minge@nordforsk.org

\section{Analyse af den nordiske velfærdsmodel}

Et nordisk team af forskere har kortlagt den nordiske models udfordringer og muligheder for udvikling i rapporten The Nordic Model - challenged but capable of reform. Læs rapporten her.

Kontakt: Tarmo Valkonen, research advisor, Research Institute of the Finnish Economy (ETLA), tarmo.valkonen@etla.fi

\section{INFRASTRUKTUR FOR VELF/ERD}

\section{Nordisk samarbejde om kliniske studier}

For få kliniske studier (test af nye behandlingsmetoder, m.m. red.) bliver foretaget på patientgrupper i de nordiske lande, og derfor har dette projekt etableret det nordiske netværk Nordic Trial Alliance, som samler repræsentanter fra både forskning, industri og patientorganisationer. Formålet er at fremme kliniske studier på tværs af de nordiske lande. I 2015 søsatte alliancen og NordForsk de første fem fælles nordiske pilotprojekter. Læs mere om projektet her.

Kontakt: Pierre Lafolie, overlæge og ekstern projektleder, Karolinska Universitetshospital, Sverige, pierre.lafolie@karolinska.se eller Maria Nilsson, seniorrådgiver og intern projektleder, NordForsk, maria.nilsson@nordforsk.org

\section{Biobanker, sundhedsregistre og sociale registre}

De nordiske lande har til sammen en guldgrube af data om deres borgere, som kan sikre helt ny viden om sundhed og velfærd. Endnu er der etiske, organisatoriske og juridiske barrierer, som gør datadeling vanskelig. Projektet har etableret et samarbejde mellem de nordiske statistikbanker, som fokuserer på at gøre det lettere for forskere i Norden at få adgang til data, så de kan oprette nordiske registre.

Læs mere om projektet her.

Kontakt: Maria Nilsson, seniorrådgiver, NordForsk, maria.nilsson@nordforsk.org 


\section{Nordisk samarbejde om højt specialiserede behandlinger}

Under ledelse af Helsedirektoratet i Norge har dette projekt etableret syv forskellige samarbejder om højt specialiseret behandling i Norden, som fokuserer på erfaringsudveksling, etableringen af nordiske databaser og udviklingen af fælles procedurer for behandlinger. Læs mere om projektet her.

Kontakt: Hans Petter Aarseth, projektdirektør, Helsedirektoratet, Norge, hans.petter.aarseth@helsedir.no

\section{Nordisk samarbejde om velfærdsteknologi}

Projektet "Velfærdsteknologi - CONNECT" har samlet de ti førende kommuner i Norden for at de sammen kan udvikle en best practice på området for velfærdsteknologi, som kan inspirere andre kommuner i Norden i deres arbejde. Også kommunernes landsorganisationer og nationale ministerier deltager.

Læs mere om projektet her.

Kontakt: Dennis Søndergård, seniorrådgiver, Nordens Velfærdscenter, dennis.soendergaard@nordicwelfare.org 
3

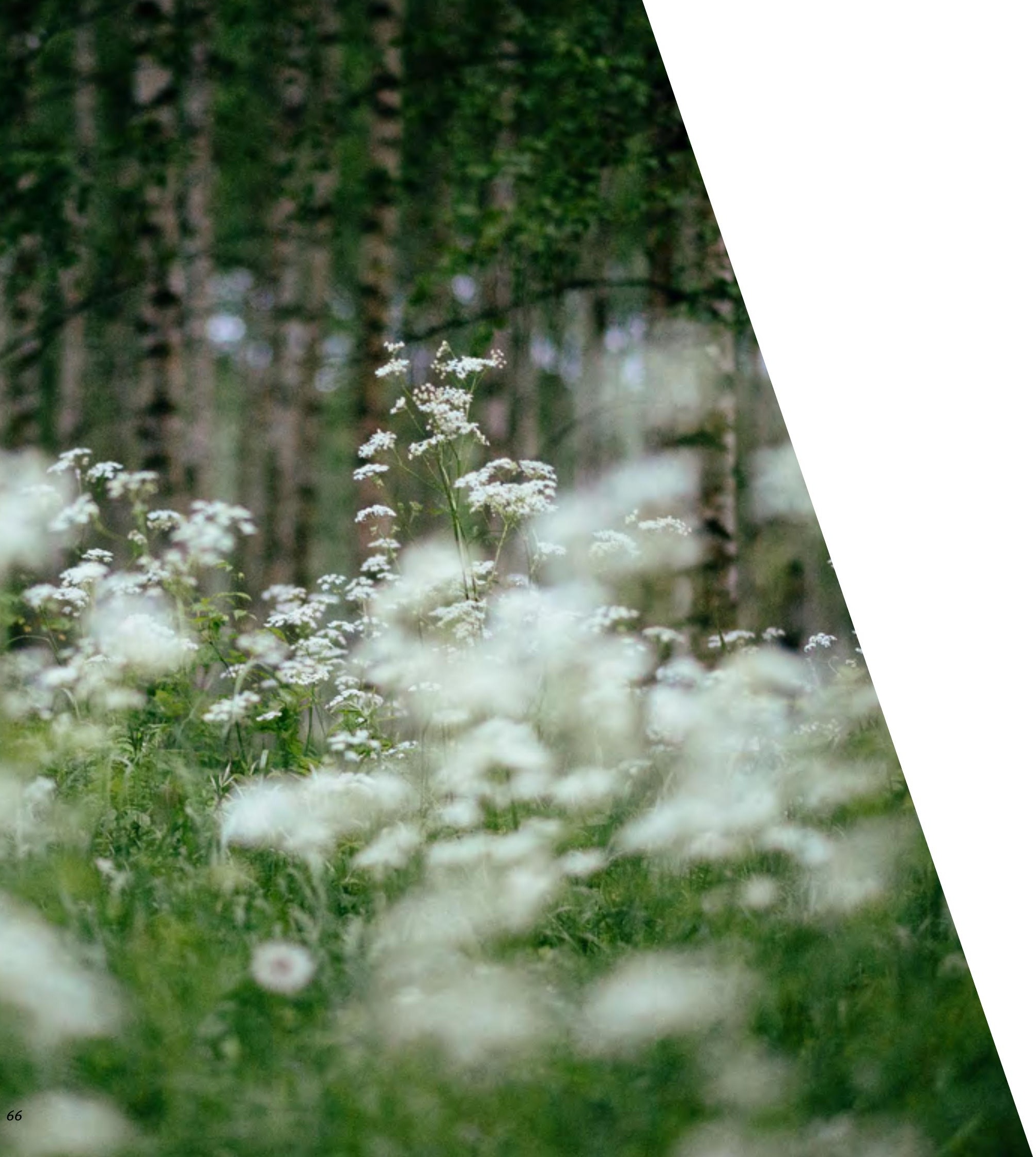




\section{Dem har vi talt med ...}

Aase Lunde, seniorrådgiver, Arbeids- og sosial-

departementet, Norge.

Anders Geertsen, afdelingschef, Nordisk Ministerråd.

Anders Rasmussen, teamleder, Fonden for Entreprenørskab, Danmark.

Ann Louise Pettersen, sygeplejerske, St. Olavs Hospital, Norge.

Annette Halvorsen, overlæge, St. Olavs Hospital, Norge.

Antti Pursula, projektleder, NordForsk \& projektchef, CSC Finland.

Claus-Göran Hjelm, afdelingsdirektør, Statistiska centralbyrån, Sverige.

Dennis Søndergård, seniorrådgiver,

Nordens Velfærdscenter.

Erland Hjelmquist, professor emeritus, Göteborg Universitet \& tidligere generalsekretær, Forskningsrådet för hälsa, arbetsliv och välfärd, Sverige.

Gillian Warner-Søderholm, associate professor og institutleder, Institut for Kultur og Kommunikation, BI Handelshøyskolen, Norge.

Guðrún Sigurjónsdóttir, konstitueret vicedirektør, Velfærdsministeriet, Island.

Halldór Guðmundsson, plejehjemsdirektør, Akureyri Kommune, Island.

Hans Petter Aarseth, projektdirektør, Helsedirektoratet, Norge.

Helen Gray, udviklingsdirektør, Center for Livslang Læring, IDAN Educational Centre, Island.
Helle Munkholm Davidsen, forskningsleder, University College Lillebælt, Danmark.

Jeanette Falck Winther, overlæge og seniorforsker, Kræftens Bekæmpelse, Danmark.

Jenny Tägström, projektleder, Nordens Velfærdscenter. Johanna Enberg, konsulent, Faugert \& Co.

Jaana Kokko, teknologisk specialist, Oulu Kommune, Finland.

Karin Sundberg, overlæge, Rigshospitalet, Danmark.

Liisa Välikangas, professor i Innovation Management, Aalto University \& Hanken School of Economics, Finland.

Magnus Magnussen, formand, Håndværkerforeningen, Færøerne.

Margaretha Allen, uddannelsesdirektør, Skolverket, Sverige.

Maria Nilsson, seniorrådgiver, NordForsk.

Marianne Aastebøl Minge, seniorrådgiver, NordForsk. Mats Rundkvist, strateg i velfærdsteknologi og e-helse, Västerås Kommune, Sverige.

Morten Friis Møller, seniorrådgiver, Nordisk Ministerråd.

Pierre Lafolie, overlæge, Karolinska Universitetssjukhuset, Sverige.

Rikke Falgreen Mortensen, specialkonsulent, Odense Kommune, Danmark.

Siv Lien, projektleder, "Holdbar Nordisk Velfærd", Nordisk Ministerråd.

Tarmo Valkonen, research advisor, Research Institute of the Finnish Economy, Finland.

Trond Nygaard, seniorrådgiver, Helse- og omsorgsdepartementet, Norge. 


\section{norden}

Nordic Council of Ministers

Ved Stranden 18

DK-1061 København K

www.norden.org

ANP 2016:704

ISBN 978-92-893-4457-9 (PRINT)

ISBN 978-92-893-4458-6 (PDF)

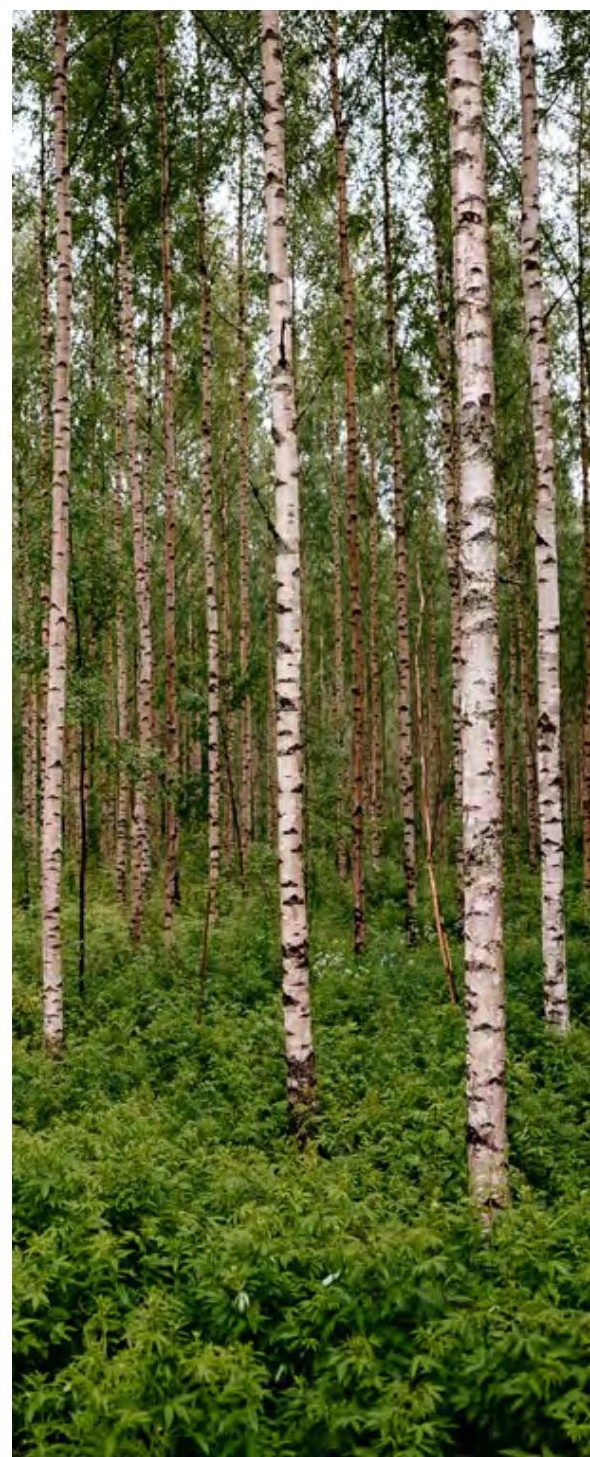

